\title{
A RECONSIDERATION OF SIPUNCULA NAMED BY I. IKEDA AND H. SATO
}

AUTHOR(S):

Edward, B.; Cutler, Norma J.

\section{CITATION:}

Edward, B....[et al]. A RECONSIDERATION OF SIPUNCULA NAMED BY I. IKEDA AND H. SATO. PUBLICATIONS OF THE SETO MARINE BIOLOGICAL LABORATORY 1981, 26(1-3): 5193

ISSUE DATE:

1981-03-30

URL:

http://hdl.handle.net/2433/176022

RIGHT: 


\title{
A RECONSIDERATION OF SIPUNCULA NAMED BY I. IKEDA AND H. SATO ${ }^{1)}$
}

\author{
Edward B. and Norma J. CUTLER \\ Utica College of Syracuse University, Utica, New York 13502, U.S.A.
}

With Text-figures $1-7$ and Tables 1-3

\begin{abstract}
The 45 species of Sipuncula (hoshi-mushi) first described by I. Ikeda and H. Sato between 1904 and 1939 are critically reviewed. The material examined consisted of all the known material identified by Ikeda and Sato plus our new collections at several of the type localities and other recent collections made by Japanese biologists. Three of the species had been earlier synonymized by other authors and we reduced the status of an additional 19 species, reaffirming the validity of 23 .
\end{abstract}

\section{Introduction}

This report is a critical evaluation of 45 species of Sipuncula (hoshi-mushi) named by Iwaji Ikeda and Hayao Sato between 1904 and 1939. The work was carried out during a six month visit to Japan wherein we examined over 3100 members of this phylum from old museum collections at the University of Tokyo and Tohoku University, recent collections made by other biologists, and new collections made by ourselves. We made contact with more than 40 biologists during our visit and obtained specimens from 17 of these (Table 1). One area which is poorly represented in our material is the Sea of Japan, especially from deep water. Subsequent papers will describe all of the species encountered and discuss the zoogeo graphy of Japanese sipunculans. We found 63 named species, perhaps 20 of these being new records for Japanese waters. Most of these new records are sublittoral forms.

Our own collecting was carried out at sites selected because they are the type localities for one or more species (Misaki, Onomichi, Kataura, Koniya and Okinawa) or at nearby locations which seemed less influenced by pollution (Tateyama and Miyake-jima). We also made small collections from coral on our return trip at Guam, Ponape (East Carolines) and Majuro (Marshall Islands) in an attempt to collect species recorded from Yap and Palau (West Carolines).

The habitats around Misaki, especially the sand/mud habitats, have undergone some changes over the past 80 years since Ikeda collected there. The number of

1) This research was made possible by Grant number INT78-14554 from the U.S. - Japan Cooperative Science Program, U.S. National Science Foundation.

Publ. Seto Mar. Biol. Lab., XXVI (1/3), 51-93, 1981. (Article 3) 
Table 1. Material examined in this study

\begin{tabular}{lrr}
\hline \multicolumn{1}{c}{ Contributors } & $\begin{array}{r}\text { Number of } \\
\text { Specimens }\end{array}$ & $\begin{array}{c}\text { Number of } \\
\text { Species }\end{array}$ \\
\hline E. Cutler, Utica College & 1230 & 32 \\
M. Horikoshi, Ocean Research Institute, University of Tokyo & 913 & 25 \\
M. Imajima, National Science Museum & 710 & 34 \\
Zoological Museum, University of Tokyo & 380 & 18 \\
T. Nishikawa, Seto Marine Biological Laboratory, Kyoto University & 295 & 25 \\
Zoological Institute, Tohoku University & many & 15 \\
M. Kosaka, Tokai University & 182 & 5 \\
I. Hayashi, Kyoto University & 70 & 13 \\
R. Yamanishi, Osaka Museum of Natural History & 36 & 10 \\
Biological Laboratory, Imperial Household & 28 & 9 \\
S. Sawada, Ehime University & 20 & 6 \\
T. Yasuda, Fisheries Exp. Station, Fukui & 19 & 3 \\
K. Osanai/M. Tsuchiya, Asamushi Marine Laboratory, Tohoku University & 17 & 3 \\
T. Okutani, National Science Museum & 15 & 2 \\
M. Yamada, University of Hokkaido & 7 & 2 \\
S. Isaka, Noto Marine Laboratory, Kanazawa University & 5 & 3 \\
Y. Honma, Sado Marine Biological Station, Niigata University & 4 & 3 \\
H. Yamashita, Seikai Regional Fisheries Laboratory & 4 & 1 \\
\hline
\end{tabular}

recreational boats, residential buildings, and commercial operations have significantly increased. We suspect that the resulting increase in petroleum products, untreated sewage, and chemicals entering the ecosystem have forced several of the infaunal species to abandon formerly suitable sites such as Koajiro Bay, near the Misaki Marine Biological Laboratory University of Tokyo. The best examples are Golfingia nigra and Golfingia misakiana, formerly found there but now found only on the other side of Tokyo Bay (G. nigra at Tateyama) or on the offshore islands (G. misakiana at Miyake-jima). Also, there exists at the Biological Laboratory of the Imperial Household specimens of Golfingia ikedai (=G. margaritacea ikedai) collected in 1926 from Koajiro Bay; now they are only found further out in clean, wave-washed sandy pockets, so the major environmental stress must have developed since 1926 . Unfortunately, Sato did not collect from this area in the 1930's. The eurytopic Siphonosoma cumanense still persists in Koajiro Bay and other areas around Misaki, as do most of the rock inhabiting species which are not down in the sediments where the toxic materials accumulate.

Of the 45 species described as new by Sato and Ikeda, three had been previously reduced to junior synonyms or subspecies in Stephen and Edmonds (1972) and we concur with that action. Of the remaining 42, we are proposing that nineteen have their status changed to subspecies or junior synonyms (Table 2). The remaining 23 species are considered as valid taxa, at least for the present.

The Zoology Department Museum at Tohoku University has a large collection of Sato's material. However, type material for only nine of Sato's species is there. Stephen and Edmonds (1972) synonymized three of these nine and in the present 
Table 2. Species synonymized in this article

\begin{tabular}{ll}
\hline \multicolumn{1}{c}{ Junior Synonym } & \multicolumn{1}{c}{ Senior Synonym } \\
\hline Aspidosiphon carolinus & Aspidosiphon elegans \\
Aspidosiphon formosanus & Aspidosiphon steenstrupii \\
Aspidosiphon grandis & Aspidosiphon cumingii \\
Aspidosiphon makoensis & Aspidosiphon steenstrupii \\
Aspidosiphon spinalis & Aspidosiphon elegans \\
Golfingia hozawai & Golfingia zenibakense \\
Golfingia ikedai & Golfingia margaritacea ikedai \\
Golfingia noto & Golfingia margaritacea soyo \\
Golfingia onagawa & Golfingia zenibakense \\
Golfingia owstoni & Golfingia vulgaris \\
Golfingia soyo & Golfingia margaritacea soyo \\
Lithacrosiphon uniscutatus & Lithacrosiphon cristatus \\
Phascolosoma deani & Phascolosoma arcuatum \\
Phascolosoma glaucum & Phascolosoma japonicum \\
Phascolosoma kurilense & Phascolosoma japonicum kurilense \\
Phascolosoma nahaense & Phascolosoma scolops \\
Phascolosoma vezonense & Phascolosoma japonicum \\
Siphonosoma formosa & Siphonosoma cumanense (sensu Stephen and Edmonds, 1972) \\
Siphonosoma hataii & Siphonosoma cumanense (sensu Cutler and Cutler. 1979) \\
Siphonosoma koreae & Siphonosoma cumanense koreae (sensu Stephen and Edmonds, \\
Siphonosoma pescadolense & 1972) \\
Siphonosoma takatsukii & Siphonosoma australe takatsukii \\
\hline &
\end{tabular}

paper we are synonymizing an additional four. Of the 23 species which we consider valid, there now exists some reference material for 13. A list of existing type specimens is shown in Table 3.

Philosophical Perspective

Ikeda was educated during the last decade of the nineteenth century when Japan was working hard to catch up with European science and technology. The community of Japanese systematists was small and his models were publications by W. Fischer, Keferstein, Selenka, Shipley, and Sluiter. Ikeda published only two papers on sipunculans during his lifetime (1904 and 1905); a third was published posthumously (1924) so this taxon was not a central and ongoing parto f his professional life.

Sato was educated during the 1920's and did all of his work on this group during the 1930's. We assume that he never came into contact with Ikeda and seemingly never inspected Ikeda's specimens. He only rarely made reference to Ikeda's species.

So, both of these men concluded their studies prior to the birth of any concept of a species as a biological population i.e., they both were operating within a framework of the typological species concept. This led to an understandable proliferation of species names based on small morphological differences, often in very few specimens 
Table 3. Currently existing type specimens

\begin{tabular}{|c|c|c|}
\hline Species & Collected at & Deposited at \\
\hline $\begin{array}{l}\text { Aspidosiphon grandis } \\
(=A \text {. cumingii })\end{array}$ & Daihanratu, Formosa by H. Sato, $3 / 19 / 36$ & 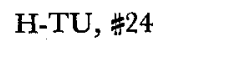 \\
\hline Aspidosiphon misakiensis & $\begin{array}{l}1 \mathrm{~km} \text { west of Tateyama Mar. Lab., Boso Pen., } \\
\text { below low tide in soft rock; } 6 / 12 / 79 \text { by Cutler. }\end{array}$ & $\begin{array}{l}\text { N-NSM } \\
\text { PN-NMNH }\end{array}$ \\
\hline Golfingia appendiculata & $\begin{array}{l}\text { Dredge St. } 21 \text { near Tsushima Island, } 205 \mathrm{~m} \text {; } \\
7 / 68 \text { by M. Imajima. }\end{array}$ & $\begin{array}{l}\text { R-NSM } \\
\text { R-NMNH }\end{array}$ \\
\hline $\begin{array}{l}\text { Golfingia hozawai } \\
\quad(=G . \text { zenibakense })\end{array}$ & Miyato-jima (Miyagi Pref.) by H. Sato. & $\mathrm{H}-\mathrm{TU}, \# 7-31$ \\
\hline $\begin{array}{l}\text { Golfingia ikedai } \\
\quad(=G . \text { margaritacea ikedai })\end{array}$ & Moroiso, Miura Pen., 1902 by I. Ikeda. & $\begin{array}{l}\text { N-NSM } \\
\text { PN-NMNH R-UT }\end{array}$ \\
\hline Golfingia misakiana & $\begin{array}{l}\text { Algal mat in tidal pool, east side of Miyake- } \\
\text { jima, } 34^{\circ} 05^{\prime} \mathrm{N}, 139^{\circ} 30^{\prime} \mathrm{E} \text {; by Cutler } 6 / 15 / \\
79 .\end{array}$ & $\begin{array}{l}\text { N-NSM } \\
\text { PN-NMNH }\end{array}$ \\
\hline Golfingia nigra & $\begin{array}{l}\text { Shallow water, Koajiro Bay, near Misaki } \\
\text { Mar. Biol. Stat. by I. Ikeda, Aug. } 1898\end{array}$ & $\begin{array}{l}\text { L-UT, \#I-42 } \\
\text { PL-NSM } \\
\text { R-NMNH }\end{array}$ \\
\hline $\begin{array}{l}\text { Golfingia soyo } \\
\qquad(=\text { G. margaritacea soyo })\end{array}$ & $\begin{array}{l}\text { St. } 551 \text {, specimen } 2 \text { by H. Sato; } 36^{\circ} 22^{\prime} 15^{\prime \prime} \\
\text { N, } 130^{\circ} 55^{\prime} \text { E. }\end{array}$ & H-TU, 俦-37 \\
\hline Golfingia zenibakense & $\begin{array}{l}\text { Shallow water near Akkeshi Marine Lab.; } \\
8 / 22 / 63 \text {. }\end{array}$ & $\begin{array}{l}\text { N-NSM } \\
\text { PN-NMNH }\end{array}$ \\
\hline Phascolion artificiosum & $\begin{array}{l}\text { St. } 1 \text { of 'T. Yasuda, } 6 / 12 / 79,36^{\circ} 50^{\prime} 130^{\circ} 40^{\prime} \\
\text { E, } 210 \mathrm{~m} \text {, Sea of Japan. }\end{array}$ & $\begin{array}{l}\text { N-NSM } \\
\text { PN-NMNH }\end{array}$ \\
\hline Phascolion dentalicolum & $\begin{array}{l}2 \mathrm{~km} \text { offshore of Asamushi Mar. Biol. Stat., } \\
\text { Mutsu Bay, } 30 \mathrm{~m}, 7 / 20 / 79 \text {; collections of sta- } \\
\text { tion. }\end{array}$ & $\begin{array}{l}\text { N-NSM } \\
\text { PN-NMNH }\end{array}$ \\
\hline Phascolion rectum & $\begin{array}{l}\text { Dredged at } 90 \mathrm{~m} \text {, Sagami Bay near Misaki } \\
\text { Mar. Biol. Stat., } 5 / 25 / 79 \text { by Cutler. }\end{array}$ & $\begin{array}{l}\text { N-NSM } \\
\text { PN-NMNH }\end{array}$ \\
\hline $\begin{array}{l}\text { Phascolosoma deani } \\
\qquad(=P \text {. arcuatum })\end{array}$ & $\begin{array}{l}\text { Feb. 1901, shallow water, South Negros, } \\
\text { Manjuyodi, Philippines by B. Dean }\end{array}$ & $\begin{array}{l}\text { L-UT, } \# \text { I-41 } \\
\text { PL-NSM } \\
\text { R-NMNH }\end{array}$ \\
\hline $\begin{array}{l}\text { Phascolosoma glaucum } \\
\quad(=P . \text { japonicum })\end{array}$ & Urata, Mutsu Bay, $7 / 13 / 26$ by H. Sato & 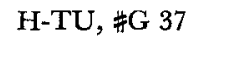 \\
\hline Phascolosoma onomichianum & $\begin{array}{l}\text { Muddy crevices between granite rocks, } \\
\text { Matsugahana, near Mukaishima Mar. Biol. } \\
\text { Stat., } 4 / 7 / 79 \text { by A. Inaba }\end{array}$ & $\begin{array}{l}\text { N-NSM } \\
\text { PN-NMNH }\end{array}$ \\
\hline Themiste minor & $\begin{array}{l}\text { Muddy crevices between granite rocks, } \\
\text { Matsugahana, near Mukaishirna Mar. Biol. } \\
\text { Stat., 4/7/79 by A. Inaba }\end{array}$ & $\begin{array}{l}\text { N-NSM } \\
\text { PN-NMNH }\end{array}$ \\
\hline Themiste hexadactyla & Off Tsuchiya, Mutsu Bay by H. Sato, 9/16/27 & $\begin{array}{l}\text { H-TU, \#G } 26 \\
\text { PL-TU, \#4-11 } \\
\text { R-NSM }\end{array}$ \\
\hline Siphonosoma amamiense & Koniya, Amami-Oshima, 1901, by I. Ikeda & $\begin{array}{l}\text { L-UT, \#I } 45 \\
\text { PL-NSM } \\
\text { R-NMNH }\end{array}$ \\
\hline $\begin{array}{l}\text { Siphonosoma formosa } \\
\quad(=\text { S. cumanense })\end{array}$ & Hattosi, Formosa by H. Sato, 3/23/36 & H-TU, \\
\hline $\begin{array}{l}\text { Siphonosoma hataii } \\
(=S . \text { cumanense })\end{array}$ & Marukyoku, Palau Island by H. Sato, 6/16/28 & H-TU, Palau 3 \\
\hline $\begin{array}{l}\text { Siphonosoma koreae } \\
\qquad(-S . \text { cumanense koreae })\end{array}$ & Gunzam Korea by H. Sato, 9/2/37 & H-TU, \#13 \\
\hline Siphonosoma mourense & Moura, Mutsu Bay by H. Satok, 8/24/26 & $\begin{array}{l}\text { H-TU, 青G-38 } \\
\text { R-NSM }\end{array}$ \\
\hline $\begin{array}{l}\text { Siphonosoma takatsukii } \\
\quad(=S . \text { australe takatsukii })\end{array}$ & $\begin{array}{l}\text { Mappu, Yap Island, West Carolines by H. } \\
\text { Satok, } 7 / 27 / 28\end{array}$ & H-TU \\
\hline
\end{tabular}




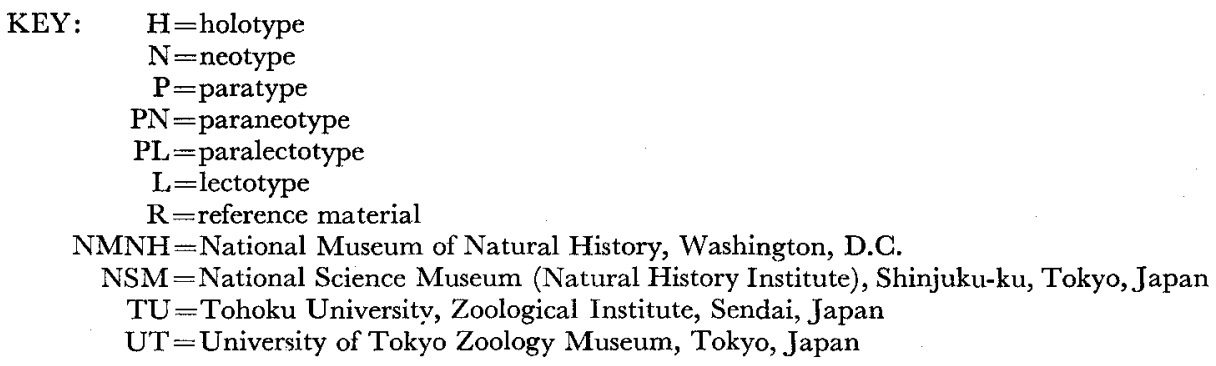

(at least 20 out of the 45 species based on one or two specimens). Another factor which further compounds the problems is that in many groups of invertebrates e.g., gastropods or polychaetes, there has been constant activity by a continuing series of biologists so that over the years revisionary work has gone on, but in a gradual fashion. With the sipunculans, we are faced with a 40-year void during which there has occurred a revolution in thought about the nature of a biological species but no parallel work on these worms.

One particular morphological feature needs comment. Much emphasis was placed on papillae size and shape by earlier sipunculan systematists. Our experience with living material from different microhabitats and material relaxed and preserved in various chemicals, plus work with the scanning electron microscope, has caused us to view this structure as one which is subject to a great deal of variation within a population (Cutler, 1979). Many of the species described by Ikeda and Sato are set apart from similar forms on the basis of papillae size and shape and we call several of these into question, especially in Golfingia and Siphonosoma.

This paper does not include complete descriptions of the species but is a review of their status based on new information and a different set of viewpoints. The reader is referred to the original works or to Stephen and Edmonds (1972) for descriptions. For each species we include all of the literature references where new material is reported, but not those which only repeat earlier records such as Murina, 1977. Sato includes all of these 45 species in his 1939 article. There have been several changes in generic names since that time i.e., Phascolosoma to Golfingia, Physcosoma to Phascolosoma, and Dendrostoma to Themiste (See Stephen and Edmonds, 1972). The subgeneric names in Golfingia follow Gutler and Murina (1977) and Cutler (1979). In this text, the spelling of Golfingia noto and G. soyo is returned to its original and proper form. In Stephen and Edmonds (1972) these were incorrectly emended to $G$. nota and $G$. soya. These are both proper nouns and used here in the nominative singular.

\section{Acknowledgments}

Our work in Japan was made possible through a grant from the U.S.-Japan Cooperative Science Program of the National Science Foundation (INT 78-14554), but was also dependent on the assistance and cooperation of many persons. Our host institution was the University of Tokyo in the persons of H. Terayama, director of Misaki Marine Biological Station and S. Kawashima, chairman, Zoology Department 
University Museum. The staff members of both these facilities helped in many ways. Our collecting efforts away from Misaki were accomplished only through help of: A. Inaba, University of Hiroshima; K. Shiomitsu, Kagoshima; A. Mori, Amami-Oshima; K. Yamazato, University of Ryukyu; J. Moyer, Miyake-jima; and S. Nemoto, Tateyama Marine Laboratory, University of Ochanomizu. The collections at Tohoku University were made accessible to us by Y. Kurihara with the assistance of Z. Kawabata. We are deeply grateful to all of the persons listed in Table 1 who allowed us to examine their collections. M. Horikoshi and S. Ohta, Ocean Res. Inst., University of Tokyo, provided valuable assistance in additional ways as did E. Ashby and M. Miyahara of the National Science Foundation, American Embassy. In addition to providing specimens, T. Nishikawa's (Seto Marine Lab.) interest in and expertise with this phylum was most helpful.

This work could not have been undertaken had it not been for the willingness of M. Shigei (Misaki Marine Biol. Stat.) and M. Imajima (National Science Museum) to serve as our hosts. They shared their time and talents as well as space with us in a most generous fashion. Finally, we deeply appreciate the assistance provided by E.J. and L.K. Cutler in the field work and housework which allowed us more time to devote to this effort.

\section{Siphonosoma (Damosiphon) formosa}

Siphonosoma formosa Sato, 1939: 373-376, pl. 20, fig. 7, text-figs. 14-17.

Type Material: One specimen collected at Hattosi, Formosa.

Material Examined: Sato's type specimen, \#6, Tohoku University, Sendai.

In Stephen and Edmonds (1972) this species was synonymized under Siphonosoma cumanense with no rationale given despite the fact that this lacks the transverse dissepiments supposedly present in S. cumanense. This feature is used at the subgeneric level in Stephen and Edmonds. When we examined the type material at Sendai, the specimen looked like a pale, medium sized $S$. cumanense without dissepiments. This matter of transverse dissepiments presence/absence was discussed in detail in Cutler and Cutler (1979) wherein we concluded that this is one of the most variable features in a population of $S$. cumanense. In light of our experience we concur in the decision of Stephen and Edmonds.

\section{Siphonosoma (Damosiphon) hataii}

Siphonosoma hataii Sato, 1935: 305, pl. 3, fig. 7, text-figs. 3-7.

Type Material: Three specimens from Marukyoku and Arukoron, Palau, West Caroline Islands.

Material Examined: Sato's type material deposited at Tohoku University, Sendai, labeled Palau 3 (2 specimens) and \$7-13.

In 1972 Stephen and Edmonds synonymized this species with Siphonosoma caro- 
linense Fisher because of their morphological and geographical similarities. When we looked at these worms they looked very much like medium sized $S$. cumanense. The supposed differences between $\mathrm{S}$. cumanense and $S$. carolinense are discussed in detail in Cutler and Cutler, 1979, wherein it is suggested that $S$. carolinense is a junior synonym of $S$. cumanense. Therefore, we support Stephen and Edmonds' earlier conclusion that this is not a valid species.

\section{Siphonosoma (Damosiphon) koreae}

Siphonosoma koreae Sato, 1939: 379-381, pl. 23, text-figs. 23-26; Stephen, 1952: 181.

Siphonosoma cumanense var. koreae Wesenberg-Lund, 1957: 4.

Type Material: One specimen collected at Gunzan, Korea.

Material Examined: Sato's type specimen, Tohoku University, Cat. \#13.

The single specimen matched Sato's description well, having the yellowish ends on the trunk. Stephen (1952) was the first to suggest that this name be reduced to subspecific rank. Wesenberg-Lund (1957) formally took this step and we concur in their wisdom.

We also examined Sato's Siphonosoma cumanense var. yapense. They exhibit no significant differences as there was yellow color on both ends of the trunk in both types. Internally $S$. koreae is exactly the same as $S$. cumanense.

\section{Siphonosoma (Siphonosoma) amamiense}

Sipunculus amamiensis Ikeda, 1904: 36-38, figs. 64-65; 1924: 31.

Siphonosoma amamiense: Sato, 1939: 371.

Type Material: Numerous specimens from Koniya, Amami-Oshima and one from Naha, Okinawa, near shore in coral sand.

Material Examined: Ten specimens at the University of Tokyo identified by Ikeda, one previously dissected, and labeled sp. n.; one specimen from Naze, no identification by Ikeda. At Tohoku University, Sendai, Cat. \#3-12, specimens identified by Sato. One specimen from Kabira Bay collected by T. Nishikawa.

These thirteen hookless specimens without transverse dissipiments and rectal caecae have their retractor muscle origins from different levels and possess between 15 and 20 longitudinal muscle bands. There are four species in the literature which fit these criteria: S. funafuti, S. joubini, S. bonhourei, plus $S$. amamiense. The first three of these are known only from the holotype and all are from the tropical Indo-West Pacific. The alleged anatomical differences are doubtful and a side by side comparison of specimens would be very interesting.

Ikeda said this species has 15 longitudinal muscle bands but in a single worm at different anterior/posterior levels one can find between 15 and 20 bundles, the 
greatest number often in the middle of the trunk. He also said there are numerous, short contractile vessel villi. In this material there were small, bubble-like swellings on the contractile vessel but no distinct villi. Ikeda's Fig. 65 does not show developed villi, especially when compared to Fig. 27 of Golfingia nigra which he also described as having short villi. It is evident to us that this tubular vessel, when shortened upon retraction of the surrounding muscles has insufficient elasticity and instead is folded or pleated in an accordian fashion giving it this irregular appearance. In most of the larger worms the body wall is thick, coarse and has distinct wart-like papillae on both ends. This species seems to be rare and restricted to the Ryukyu and Amami Islands. We collected 100 members of this genus from these islands but found no representatives of this species.

We have designated the specimen from the University of Tokyo that had been dissected as the lectotype. It is deposited at the University of Tokyo Zoology Museum, Cat. \#I-45. Paralectotypes taken from the same bottle are deposited at the National Science Museum, Tokyo, and reference specimens are at the National Museum of Natural History, Washington, D.C.

\section{Siphonosoma (Siphonosoma) mourense}

Siphonosoma mourense Sato, 1930: 6-8, pl. 1, figs. 2-4; 1937a: 148-149, pl. 3, fig. 9; 1939: 370-371; Leroy, 1936: 425 .

Type Material: Several specimens from Moura, Mutsu Bay, Japan.

Material Examined: Sato's type material at Tohoku University, Sendai, Cat. \#183, G 38, Sta. 23; also other specimens of Sato's, Cat. \#1-2, 1-3, 4-10, 4-21, 5-4.

Most of the specimens at Tohoku University are well preserved and compare well with Sato's description. Superficially, externally, these closely resemble $S$. cumamense. The obvious internal differences are that these have no transverse dissepiments, and the retractor muscles arise from different levels, the dorsal pair anterior to the ventral pair. The number of longitudinal muscle bands ranges from 20-25 rather than the constant 22 that Sato recorded. This appears to be a valid species requiring no additional comment. The holotype is at Tohoku University, Sendai, with a reference specimen deposited at the National Science Museum, Tokyo.

\section{Siphonosoma (Siphonosoma) pescadolense}

Siphonosoma pescadolense Sato, 1939: 376-379, pl. 20, fig. 8, text-figs. 18-22.

Type Material: One specimen from the beach at Mako, Formosa. Material Examined: None.

As we were unable to locate the single representative of this species, our comments are based on our reading of the literature and our experience with related 
forms. In his text Sato (1939: 379) sets this worm apart from other hooked species (S. australe, S. takatsukii, $S$. parvum and $S$. arcassonense) on the basis of the number of longitudinal muscle bands and by the features of the skin papillae. In his key he separates it from $S$. takatsukii because $S$. pescadolense has thin, somewhat translucent skin as opposed to thick opaque skin. If we set $S$. parvum aside as it is currently in a different subgenus and $S$. arcassonense because of its peculiar yellow tubular glands, we are left with two species similar to this one: $S$. australe and $S$. takatsukii. All three of these may have 15 longitudinal muscle bands so for these three that distinction of Sato's is meaningless. The issue of papillae form and size is discussed elsewhere but in our minds this alleged difference, together with the thickness of the skin, can he disregarded as a byproduct of the state of contraction of the body musculature at the time of preservation.

Sato illustrates the hooks (spines) of this species but does not give measurements. Measurement of his illustrations and calculations back, show the hooks are just under $0.14 \mathrm{~mm}$ while in $S$. takatsukii are $0.13 \mathrm{~mm}$; both then are small and bluntly pointed. Given all the morphological and ecological similarities it is reasonable that $S$. pescadolense should be reduced to the status of a junior synonym of $S$. takatsukii which we treat as a subspecies of $S$. australe.

\section{Siphonosoma (Siphonosoma) takatsukii}

Siphonosoma takatsukii Sato, 1935: 308-310, pl. 3, fig. 8, text-figs. 8-10.

Type Material: One specimen collected at Mappu, Yap Island.

Material Examined: Type specimen deposited at Tohoku University, Sendai.

This single, well preserved specimen matches Sato's description very well. In many ways this worm is identical with $S$. australe. The smaller, blunter hooks may be a real difference or an anomolous individual variation. Sato collected numerous Siphonosoma on Yap but only this single hooked specimen. We think that a subspecific ranking of this species under $S$. australe is appropriate. This latter species is common in the southwest Pacific Ocean so it is reasonable to expect it could occur in Yap. The distribution pattern of this expanded taxon is still a typical Indo-West Pacific, tropical intertidal one, including the Formosa record of a thin skinned individual ( $S$. pescadolense) and this one from Yap with smaller, blunter hooks (S. takatsukii). The latter character would serve to differentiate this northeastern subspecies from the nominate form.

\section{Golfingia (Apionsoma) misakiana}

Phascolosoma misakianum Ikeda, 1904: 7-9, pl. 1, fig. 3, pl. 3, figs. 30-33.

Golfingia misakiana: Amor, 1975: 117, fig 3; Cutler, 1973: 140; Cuiler, 1979: 370; Cutler and Cutler, 1979; Cutler and Murina, 1977: 180; Fischer, 1919: 281; Fisher, 1952: 393; Rice, 1978: 85.

Type Material: Several specimens from between tide marks, under seaweeds cover- 
ing tufaceous sandstone in front of Misaki Mar. Lab.

Material Examined: Identified by Cutler, collected by Cutler, Imajima, Horikoshi, Hayashi, Kosaka from 0-150 meters: 5 specimens from $\mathrm{Ka}$ bira Bay, 5 from Kyushu and south, 87 from Suruga Bay, Izu Islands, Ogasawara Islands, 1 from Wakasa Bay.

None of Ikeda's type material could be located. These 98 animals are of special interest to us as this species has been the subject of much attention in recent years (see above). They were collected from areas bounded by central Honshu/Izu Islands/Ogasawara Islands to the northeast and Yaeyama Islands to the southwest, at depths ranging from the intertidal to $150 \mathrm{~m}$. More detailed station data will appear in a later paper. Repeated attempts were made around Misaki (type locality) to locate this species but without success. However, on Miyake-jima we collected 38 specimens from under algal mats in the bottom of tide pools. The trunk size in this material ranges from 2-7 $\mathrm{mm}$.

The variations in this species' anatomy have been discussed elsewhere and these Japanese specimens fit the description of Ikeda. Some of these worms, especially the smaller ones from deeper water, showed atypical nephridial development having only a single lobe on one or sometimes both sides. Rice (1978) shows this to be normal in juvenile animals so these specimens may simply have not yet reached the stage in their ontogeny when the second lobe develops. The number of spinelets on the base of the hook can not always be clearly seen but there are between four and six spinelets on most. One troublesome feature is introvert length, an extremely extensible, plastic feature. This may be one character which shows geographic variation as in the Indian Ocean material it was more than nine times the trunk length measuring from the nephridiopore. Rice's (1978) Gulf of Mexico and Fisher's (1952) California material were only about four to six times as long. In this collection, the longest completely extended introvert is about five times the trunk. In Cutler (1979: 572) wherein this subgenus is reviewed and redefined he states that the introvert length of $G$. misakiana is 10-12 times the trunk length. This also appears in the key (p. 583) and should be modified to take the above into consideration. The physical/chemical environment of the animals immediately prior to preservation strongly influence this character.

A neotype collected at Miyake-jima has been deposited at the National Science Museum, Tokyo, and paraneotypes from the same location are in the National Museum of Natural History, Washington, D.C.

\section{Golfingia (Golfingia) appendiculata}

Phascolosoma appindiculatum Sato, 1934: 7-10, pl. 1, fig. 4, text-figs. 7-10.

Golfingia appendiculata: Cutler, 1977a: 139; Murina, 1964: 224-227, fig 4; 1978: 122.

Type Material: Three specimens from $288-527 \mathrm{~m}$ in Tosa Bay, Shikoku, $33^{\circ} 15^{\prime}$ $\mathrm{N}, 133^{\circ} 49^{\prime} \mathrm{E}$. 
Material Examined: Seven specimens from M. Imajima collected off Tsushima Island at $205 \mathrm{~m}$.

These seven worms are referred to this taxon with some reservation. They range in trunk length from $10-25 \mathrm{~mm}$ and are therefore much smaller than Sato's $120 \mathrm{~mm}$ type which we were not able to locate. There are two basic differences: the ventral retractor muscles originate near the middle of the trunk $(50 \%$ of the distance from nephridiopore to posterior end) as opposed to the anterior 1/7 in Sato's or $1 / 3$ as in Murina (1964); secondly, the tail appendage is much shorter (1-2 mm). However, if one converts Sato's figures to percentages, ours are comparable (about $10 \%$ of the trunk). The issue of retractor origins may be explainable as a size/age related factor or possibly a genetic variation. These come from north of Kyushu while the type locality is south of Shikoku and are, therefore, biologically isolated, but on a global scale relatively near.

Aside from the above characters, these specimens agree with Sato's description. We affirm the validity of this species. Because of our uncertainty with these particular specimens, we are not now setting aside a neotype. However, reference material is deposited at the National Science Museum, Tokyo, and the National Museum of Natural History, Washington, D.C.

\section{Golfingia (Golfingia) glossipapillosa}

Phascolosoma glossipapillosum Sato, 1934: 10-12, pl. 1, fig. 5, text-figs. 11-14.

Type material: Several specimens from $249 \mathrm{~m}$ off Hamada, Iwami Province, (now Shimane Prefecture), Japan Sea, $35^{\circ} 37^{\prime} \mathrm{N}, 131^{\circ} 02^{\prime}$ E.

Material Examined: None

Sato's original material consisted of one good specimen plus other specimens which were imperfect and-broken into fragments. We were unable to locate his specimens and in the new material from the Sea of Japan we found nothing resembling his description. This is a taxon which is very similar to Golfingia margaritacea in all ways except the shape and size of the skin papillae, these being scattered over the whole trunk, large, and tongue shaped. Two other minor differences sometimes used to distinguish this from G. margaritacea of more questionable significance are the alleged absence of a rectal caecum (in other species of Sato's where type material was available, we found this structure where he had overlooked it); and the nephridiopore being at the level of the anus instead of anterior to it (the distances involved here are very small and this can be a subjective matter).

This form seems to be at one end of a graded series of Golfingia margaritacea-like animals, these having the most pronounced papillae development. We shall at this time resist the temptation to reduce this to subspecific rank but have serious doubts about its biological meaningfulness. Hopefully, additional deep-water collections in the future from the Sea of Japan might help clarify this complex of 
margaritacea-like taxa.

\section{Golfingia (Golfingia) ikedai}

Phascolosoma japonicum Ikeda, 1904: 5-7, figs. 2, 28-29; Chin, 1947: 100.

Golfingia ikedai: Fisher, 1950: 550.

Type Material: Numerous specimens from shallow water in clean sand in narrow fissures of rocks on the coasts of Tokyo and Sagami Bays, especially near Misaki Marine Laboratory.

Material Examined: 50 specimens at University of Tokyo and Misaki Marine Lab., collected by Ikeda.

80 specimens collected by Cutler in Sagami Bay, most near Misaki; 8 specimens collected by Imajima from Sagami and Suruga Bays; 1 specimen collected by Nishikawa near Kushimoto, Kii Peninsula.

In the vicinity of the type locality we collected dozens of members of this subgenus. At the University of Tokyo Museum we found several dozen members of this subgenus from the type locality identified by Ikeda to genus but no legible labels with this species' name. There is no doubt that this is the same population that Ikeda described as Phascolosoma japonicum.

At the end of his description Ikeda made no comparison to any other member of this genus. Sato never recorded this species and in his 1939 key separated it from Golfingia margaritacea on the basis of flattened skin bodies vs. papillae on the trunk. In Stephen and Edmonds' (1972:84) key to this subgenus, they were unable to find anything to separate these two species yet left $G$. ikedai as a valid, separate taxon. In Ikeda's description he uses both terms (skin bodies and papillae) to refer to the same structures. The use of these terms by different authors over the years is neither consistant nor clear.

There are three characters that have not been emphasized in the literature but which require comment i.e., the eyespots, contractile vessel, and rectal caecum. Ikeda said his animals had brown eyespots but our examination showed this feature to be present in only a few individuals. It is possible that this pigmentation was lost through the bleaching action of the preservative. If so, it is not a useful character. The contractile vessel in this Japanese population often exhibits a peculiar folding or bubbling along its length, similar to that found in Golfingia capensis. The vessel itself is larger than in many Golfingia and this vesicular nature is most obvious in large, strongly contracted forms; those with the introvert extended have a more normal, smoother surface. These vesicles are clearly not villi as in the subgenus G. Thysanocardia. We suggest the following: this structure increases in size in direct proportion to the number and size of the tentacles (as seen in Themiste and Golfingia (Thysanocardia) and that as a blind compensation sac, the fluid content of the sac (vessel) increases when the tentacles are withdrawn. Also, it is not a muscular/ 
elastic structure as are adjacent retactor muscles. Therefore, when forced into a smaller space, upon retraction, it is thrown into folds which, when viewed from above, look like bubbles or vesicles. The rectal caecum is usually, but not always, present and, therefore, should not be weighted heavily as a taxonomic character.

Golfingia margaritacea is a very widespread, eurytopic form with many described subspecies and in our judgement $G$. ikedai is very clearly not a distinct species. A more appropriate placement would be as a subspecies of $G$. margaritacea. This form differs from the nominate form in having a large contractile vessel which has a vesicular, bubble-like appearance, most pronounced in contracted specimens. The occasional occurance of darkly pigmented eyespots and occasional absence of the rectal caecum are also characteristic of the subspecies.

A neotype has been deposited at the National Science Museum, Tokyo, paraneotype at the National Museum of Natural History, Washington, D.C., and additional reference material at the Zoology Museum, University of Tokyo.

\section{Golfingia (Golfingia) noto}

Phascolosoma noto Sato, 1934: 14-16, pl. 1, fig. 7, text-fig. 17.

Type Material: Two specimens from $424 \mathrm{~m}$ off Noto Peninsula, $37^{\circ} 21^{\prime} \mathrm{N}, 136^{\prime}$ $09^{\prime} \mathrm{E}$.

Material Examined: None.

Sato's two specimens could not be located. We did have access to some material from Wakasa Bay just south of the type locality and found Golfingia margaritacea and $G$. signa, but nothing fitting this description.

On a side by side comparison with $G$. soyo, the primary difference in their descriptions seems to be that $G$. noto has small pear-shaped papillae on the introvert while $G$. soyo has larger cone-shaped papillae. A secondary trait is the ventral retractor origin ( $1 / 3$ vs $1 / 2$ the distance to the posterior end of the trunk). The sole feature that seems to distinguish this from $G$. margaritacea is papillae size and shape. In the following discussion of $G$. soyo, for which we have type material, this is also discussed. Both $G$. soyo and $G$. noto were collected from deep water in the Sea of Japan north of Central Honshu.

Based on our experience with Sato's material and other fresh material in this subgenus, we conclude that $G$. noto is clearly synonymous with $G$. soyo and furthermore, that both merit, at best, subspecific rank under $G$. margaritacea. In accordance with recommendation $24 \mathrm{~A}$ of the International Code of Zoological Nomenclature, we would retain $G$. soyo as the appropriate name of this combined taxon as type material is present at Tohoku University, Sendai. This taxon differs from the nominate form by having pear or cone shaped papillae on the base of the introvert. It should be noted that Japanese pears have a shape unlike American pears. 


\section{Golfingia (Golfingia) okinoseana}

Phascolosoma okinoseanum Ikeda, 1904: 9-12, figs. 4, 34-38.

Type Material: One specimen dredged at $670 \mathrm{~m}$ near Okinose Bank, Sagami Bay. Material Examined: None.

This single specimen could not be located. This species belongs to the group of Golfingia (Golfingia) without introvert hooks. In . Stephen and Edmonds (1972:84) the key to this subgenus required one to say that "the posterior end is not drawn out into a prominent appendix-like structure". However, Ikeda says this has a "small and slender tail-like process" as is also shown in his figures.

We examined 531 sipunculans from the area of the type locality (over $300 \mathrm{~m}$ in Sagami and Suruga Bays). Eighty-three were Golfingia but nothing similar to this form was seen. Therefore, we cannot help clarify the status of this rare and peculiar worm. Sato's G. glossipapillosa from the opposite side of Honshu is intriguingly similar but with no material for comparison we do not want to say more at this point in time. Both species have the same internal organization and the differences seem restricted to papillae shape and size, but both have fairly large papillae over all or part of the trunk.

\section{Golfingia (Golfingia) owstoni}

Phascolosoma owstoni Ikeda, 1904: 12-15, figs. 5, 39-44.

Type Material: One specimen dredged from $300 \mathrm{~m}$ in Uraga Channel.

Material Examined: None

The single worm Ikeda used as the basis for this species came from $300 \mathrm{~m}$ at the mouth of Tokyo Bay. We made collections down to $100 \mathrm{~m}$ in this area and examined deeper collections made by others without finding such an animal. We did find the related species $G$. elongata and $G$. vulgaris. One interesting feature of this species is the presence of only three retractor muscles. This trait has been used by Murina (1975) to erect a new subgenus, Dushana, but Gibbs (1977:14) has pointed out how in $G$. vulgaris there are about $5-10 \%$ of the members of some populations having only three or two retractor muscles. Ikeda obviously felt this condition to be unnatural and Sato (1939) later included it along with others having four retractor muscles as have subsequent authors. In his key, Sato (1939:447) separated $G$. owestoni from $G$. vulgaris on the basis of papillae shape and size at the base of the introvert. In Stephen and Edmonds' key (1972:83) these are separated because $G$. vulgaris presumably lacks a rectal caecum, yet in Stephen (1960:19) as well as others, $G$. vulgaris is said to have a rectal caecum.

Ikeda never used the name G. vulgaris in his publications, but Sato (1939:404) records it from several Japanese locations. There is a contradiction in Sato (1939) wherein his key he says the papillae on the base of the introvert are cylindrical and 
very tall $(0.13 \mathrm{~mm})$ but in his description he says they are roundish $(0.03-0.04 \mathrm{~mm}$ tall).

Our analysis of this situation leads us to conclude that this single worm of Ikeda's is a representative of the widespread species $G$. vulgaris with one retractor muscle absent. As noted in Stephen and Edmonds (1972:111-113) G. vulgaris is a plastic species with many variations on the basic theme. Therefore, we propose that $G$. owstoni is a junior synonym of $G$. vulgaris as it lacks any features distinctive at the species level.

\section{Golfingia (Golfingia) signa}

Phascolosoma signum Sato, 1934: 16-17, pl. 1, fig. 8, text-fig. 18.

Type Material: Three specimens from $658 \mathrm{~m}$ in Wakasa Bay, $36^{\circ} 19^{\prime} 35^{\prime \prime} \mathrm{N}, 135^{\circ}$ $34^{\prime} 28^{\prime \prime} \mathrm{E}$.

Material Examined: Two specimens from 307 and $330 \mathrm{~m}$, Wakasa Bay, collected by I. Hayashi.

These two worms have trunks measuring 10 and $17 \mathrm{~mm}$ as compared to Sato's three worms, one of which was $45 \mathrm{~mm}$ long. Our two worms come from the type locality but from shallower water $(307-330 \mathrm{~m}$ vs. $658 \mathrm{~m})$ and are referred to this species with some reservations. This species is very similar to Golfingia margaritacea but there is a set of four characters that allegedly set it apart: posterior end of trunk pigemented and with wave-like ripple marks (not reticulations); dorsal retractors very slender, like spindle or fixing muscles; papillae of various shapes (spheres, pears, and cylinders); and nephridiopores at the same level as the anus (not anterior to it). Taking this last feature first, Sato's (p 17) words are, "...nearly at the same level as the anus." This, in the absence of any figure, is open to interpretation as to whether it is anterior or posterior; Sato does not make that clear. The issue of papillae shape we have discussed earlier.

Our two worms have transparent body walls except for the posterior 20-30\% which has an orange color, a smaller diameter, more obvious cylindrical papillae, and wavy ripple marks on the surface much like Sato's text-fig. 18. However, the dorsal retractor muscles are of normal dimensions, not as Sato described; the nephridia are just anterior to the anus; and no spherical or pear-shaped papillae are visible. So, these match in some ways but not in all of the 'key' characters, leading to our hesitancy. This may be the result of the size differences (ours being juveniles), but we cannot be certain. Because of our uncertainty about this identification we are not designating any neotype from this material. It may be more appropriate to consider this taxon a subspecies of Golfingia margaritacea (there are already eight described subspecies) as the differences are minimal. More material is needed before a definitive statement will be made. 


\section{Golfingia (Golfingia) soyo}

Phascolosoma soyo Sato, 1934: 17;20, pl. 1, fig. 9, text-figs. 19-21.

Type Material: Specimen $\$ 2$, Sta. 551, found at $36^{\circ} 22^{\prime} 15^{\prime \prime} \mathrm{N}, 135^{\circ} 55^{\prime} \mathbf{E}$.

Material Examined: Tohoku University, Sendai: Cat. \# 7-37, Sta. 551, 4 specimens, one of which is the type; \#6-7, Sta. 585, 4 specimens; $\$ 54$, Sta. 652, 1 specimen listed as type but Sato designated this as paratype. Three specimens collected by Y. Yasuda from Japan Sea, $36^{\circ} 20^{\prime} \mathrm{N}, 135^{\circ} 40^{\prime} \mathrm{E}, 535 \mathrm{~m}$.

The nine well preserved worms from Tohoku (ranging in size from $30-80 \mathrm{~mm}$ ) with four retractor muscles and no hooks match Sato's description in general. The three recently collected specimens, despite the poor preservation, seem also to fit best into this taxon. The emphasis Sato placed on papillae size and shape is unfortunate. As other authors have pointed out, these epidermal glandular structures vary in size and shape with the state of contraction of the body wall. The thickness of the body wall and the appearance of circular ridges and furrows around the anterior part of the worm is evidence of a strongly contracted state.

These individuals have papillae on the base of the introvert which are a little taller than in some related species e.g., G. margaritacea but whether that difference is biologically significant is doubtful. Another supposed difference from G. margaritacea is the absence of a rectal caecum in this species. In fact a good size caecum is present on the rectum. It is not visible on the exposed straight part but is partly covered by the first esophageal coil. Also, in the worms in Sta. 551, the nephridia are 1 or $2 \mathrm{~mm}$ anterior to the anus, not $10 \mathrm{~mm}$ as Sato stated.

As earlier discussed in the section on $G$. noto, these two taxa are herein considered synonyms and are combined under this name as type material exists. In general appearance, habitat, and anatomy this species is remarkably similar to $G$. margaritacea. As a subspecies of $G$. margaritacea, this taxon (which we are herein reducing) differs from the nominate form by having larger papillae on the introvert.

\section{Golfingia (Siphonoides) quadrata}

Phascolnsoma quadratum Ikeda, 1905: 170-171, pl. 8, figs. 1-4.

Type Material: One specimen from sandy beach, Manjuyodi, South Negros, Philippines.

Material Examined: None.

The single worm upon which Ikeda based this species could not be located and we did not reach the type locality to make new collections. Murina (1967a) named a new species, $G$. mexicana, from four specimens in the Gulf of Mexico and separated it from G. quadrata on two features: introvert length and skin body shape. Murina's worms had introverts 3-4 times the trunk length while in Ikeda's animal this region 
was about equal to the trunk. The skin bodies on G. quadrata are described as being rectangular while in G. mexicana they are oval or circular. Whether these are biologically significant differences, an artifact of preservation/body contraction or a geographical variation is uncertain but open to question.

We do not propose any change in the status of this taxon at this time but merely point to the fact that in 75 years no additional specimens have been found. We also raise the possibility that $G$. mexicana may be a subspecies or junior synonym. Additional collections from the Philippines might help clarify this matter.

\section{Golfingia (Thysanocardia) hozawai}

Phascolosoma hozawai Sato, 1937a: 158-160, pl. 4, fig. 15, text-figs. 5-8.

Type Material: One specimen at Miyato-jima, Miyagi Prefecture.

Material Examined: One specimen, catalogue \# 7-31, at Tohoku University, Sendai.

This worm has its introvert about $2 / 3$ retracted but is in good condition for having been dissected. Using the nephridiopore to mark the anterior end, the trunk measures $38 \mathrm{~mm}$ in length. Several discrepancies were noted in Sato's discription. The introvert is much more than one half the trunk length; it exceeds it by a significant amount and perhaps even twice its length if extended naturally. The nephridia are $7 \mathrm{~mm}$ anterior to the anus, not 10. The pair of ventral retractor muscles originate at about $65 \%$ of the distance to the posterior end, not $80 \%$. A distinct rectal caecum is present at the beginning of the rectum, partially hidden by the esophageal loops. The issue of papillae shape is difficult and troublesome, as mentioned elsewhere. One finds many papillae but of various sizes and shapes, generally mammiform or cone-shaped, as in other species.

We believe that this individual does not merit specific rank. The differences between it and Golfingia zenibakense are very slight and they should be considered as one species, $G$. zenibakense being the senior synonym.

\section{Golfingia (Thysanocardia) hyugensis}

Phascolosoma hyugensis Sato, 1934: 12-14, pl. 1, fig. 6, text-figs. 15-16.

Type Material: One specimen from $472 \mathrm{~m}$ off Miyazaki in Kyushu, $31^{\circ} 41^{\prime} \mathrm{N}$, $131^{\circ} 46^{\prime} 40^{\prime} \mathrm{E}$.

Material Examined: None.

This single animal could not be located, we were unable to collect near the type locality, and were not able to locate deepwater collections made by others in this vicinity. So, the possibility that this worm does represent a population is still untested.

The most striking trait distinguishing this form from others in this subgenus is 
the nature of the tentacular crown. The general pattern in Thysanocardia is a complex array of over 100 tentacles, in many rings. Sato describes this worm as having only seven or eight tentacles in a single ring; a very atypical Thysanocardia arrangement. Otherwise, this form is very similar to several others but especially $G$. hozawai which we herein consider to be synonymous with $G$. zenibakense. More collecting near the type locality is necessary to test the validity of this species (individual) but for the moment its status shall remain unchanged but suspect.

\section{Golfingia (Thysanocardia) nigra}

Phascolosoma nigrum Ikeda, 1904: 3-5, figs. 1, 25-27; Chin, 1947: 101.

Type Material: Numerous specimens from Misaki Marine Laboratory, Tokyo Bay, and the Inland Sea from muddy bottom.

Material Examined: Forty specimens identified by Ikeda stored at the University of Tokyo.

73 specimens collected from the south coast of Honshu and Shikoku, from Hiroshima to Fukushima Prefecture, collected by Imajima, Nishikawa, Sawada, and Cutler.

These specimens compare well with Ikeda's description but the following observations modify the construct slightly. The name of this species was based on its color, but none of Ikeda's worms are black now. Furthermore, only one of the newly collected worms is dark grey/back; most are a medium or light grey and the smaller ones are very pale off-white. A similar variation is noted in tentacle color. Ikeda said the tentacles are clear violet while we found that only a few were completely pigmented, most had patches of color but some lacked pigmentation entirely. The number of tentacular ridges varies from $12-16$ not $15-16$ as he stated (Fig. 1A).

Ikeda said the introvert is 2.5 times the trunk length but in ten of his specimens, we measured a range from 1.6-2.6, with most greater than two times the trunk length. The retractor muscles originate not just at the beginning of the posterior third $(67 \%)$ but anywhere between 55-75\% of the distance to the posterior end of the trunk. Ikeda also stated that the contractile vessel villi were short and found only on the posterior parts of the contractile vessel, but we observed them along the whole length of the esophagus decreasing in size anteriorly but posteriorly becoming quite long, bifurcating and branching as in other members of this subgenus. The nephridia are described as being of "considerable length" which we found to be from 25-50\% of the trunk length. Ikeda commented that these open "a certain distance in front of the anus". We measured this distance to be $4-6 \mathrm{~mm}$ in worms with $25-35 \mathrm{~mm}$ trunks.

This appears to be a well founded, valid taxon. However, it seems to have disappeared from the Misaki area where it was the commonest in Ikeda's time. A lectotype has been deposited at the University of Tokyo Zoological Museum, paralectotypes at the National Science Museum, Tokyo, and reference material at the 


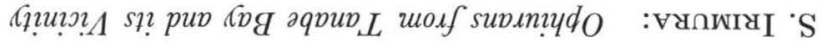
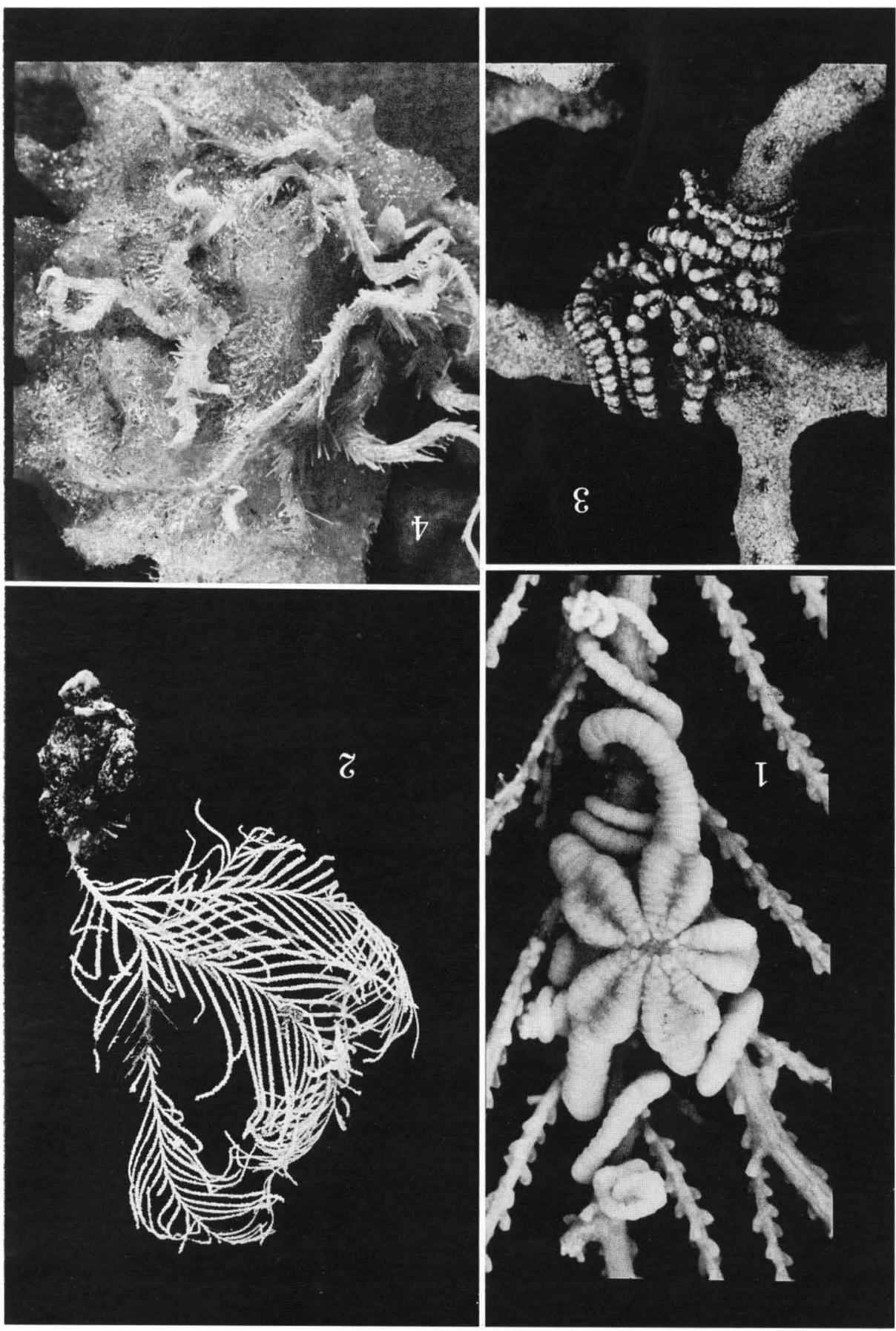

I GLVTd

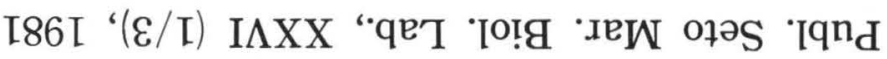




\section{Golfingia (Thysanocardia) zenibakense}

Phascolosoma zenibakense Ikeda, 1924: 29;30, fig. 1; Sato, 1930: 17-20, pl. 3, figs. 11-12, text-fig. 5; 1937a: 153-154; Okuda, 1946: 223.

Type Material: Numerous specimens stranded on a beach in stormy weather at Zenibako, near Otaru, Hokkaido.

Material Examined: At Tohoku University, Sendai: catalogue \#3-29, 1 specimen; \# 4-4, 1 specimen; identified by H. Sato.

Five specimens collected in 1943 and 1963 at Akkeshi Marine Laboratory, Hokkaido University.

These seven worms vary in trunk length from $50-70 \mathrm{~mm}$. Their introverts range from 1-2 times the trunk length. The one pair of retractor muscles originate between $60-70 \%$ of the distance to the posterior end of the trunk and the nephridia are $2-4 \mathrm{~mm}$ anterior to the anus. At least two specimens have a rectal caecum on the inside of the last intestinal coil near the spindle muscle, just at the beginning of the rectum. The contractile vessel villi are distributed along most of the length of the esophagus and are of various lengths, the longer ones being branched as in other members of this subgenus. The tentacles are arranged in 20 double rows and each row bears 30-40 tentacles, making a total of 600-800 individual subdivisions.

These observations are not in total agreement with Ikeda's original description. Sato (1930:19) also found some of these same descrepancies. Both Sato (1930) and Ikeda's (1924) statements were based on single individuals. It is clear that this population exhibits variation in such characters as introvert and contractile vessel villi length, presence of rectal caecum, point of origin of the retractor muscles, and others. Nevertheless, it is probable that this represents a distinct species which includes as a junior synonym Golfingia hozawai (as mentioned in that section). It is similar to $G$. nigra but the number of tentacle rows is greater (20 vs. $12-16$ ), the introvert length is usually shorter (1-2 vs. $2-2.5)$, the nephridia are shorter (10-15\% of the trunk vs. 25-50\%), the rectal caecum position differs (near beginning vs. in middle of rectum), and the skin texture is usually different (smooth vs. rough and coarse). Some of these differences are subjective and not always clear, but together they form a complex of features which can be useful. It should be pointed out that these two species seem to be geographically separated ( $G$. zenibakense is restricted to northern Honshu and Hokkaido and G. nigra is off central and southern Honshu).

We designate one of the worms from Akkeshi Marine Laboratory as a neotype, deposited at the National Science Museum, Tokyo. Paraneotypes from the same station are at the National Museum of Natural History, Washington, D.C.

\section{Phascolion artificiosum}

Phascolion artificiosus Ikeda, 1904: 18-20, figs. 6, 50-55.

Type Material: Two specimens from gastropod shells dredged at $659 \mathrm{~m}$ in Sagami 
Bay.

Material Examined: 14 specimens, 210 and $535 \mathrm{~m}$ in the Sea of Japan collected by T. Yasuda.

1 specimen dredged at $205 \mathrm{~m}$ off Tsushima Island by M. Imajima.

1 specimen from $20 \mathrm{~m}$ in Sagami Bay collected by the Biological Laboratory, Imperial Household.

Ikeda's two specimens could not be located and in the 448 members of this genus recently collected from deep water in Sagami and Suruga Bays we found no worms matching this description, except for the single specimen from $20 \mathrm{~m}$ collected in 1964 by the Imperial Household. There were over 200 specimens which match except that they do have hooks and we consider them to be P. strombi.

The 16 specimens we assign to this taxon are close to this construct but most were collected at some distance away from the type locality. The trunk length of our specimens taken from gastropod and scaphopod shells ranges from 10-40 mm and the introverts are 1.5-2.0 times the trunk lengths. One $5 \mathrm{~mm}$ worm has an introvert shorter than the trunk. The color is gray or pinkish tan except at the anterior end of the trunk where it is darker gray. This same region is supplied with many large papillae and, in many, associated colonies of epizoic hydrozoans. The holdfasts are generally located in the central third of the trunk and have the typical $\mathrm{U}$ or $\mathrm{V}$ shape, many with a single apical spine. Hooks are absent. There are usually 12-20 normal tentacles present but the $5 \mathrm{~mm}$ worm has only 8-10.

Internally the single, short nephridium is attached to the trunk wall for about one half its length and it opens $2-4 \mathrm{~mm}$ anterior to the anus. There is a well developed rectal caecum present and 3-5 fixing muscles attaching the gut to the body wall in the larger worms. The undivided dorsal retractor muscle originates at the posterior end of the trunk. The ventral muscle has two distinct roots which straddle the mid-ventral line posterior to the bifurcating termination of the ventral nerve cord. This muscle is about half the diameter of the dorsal muscle but significantly larger than the comparable muscle in $P$. strombi.

Other authors have pointed to the similarity of this taxon to $P$. botulum. The two alleged differences are the number of roots on the dorsal retractor muscle (2 vs. 5) and the nephridium attachment (free in $P$. artificiosum and fixed in $P$. botulum). This recent material has an undivided dorsal retractor muscle and a partially fixed nephridium. If more material of both types can be collected, a comparison might show these to be synonymous.

Our perception of $P$. artificiosum leads us to the conclusion that it is very close to the common, widespread $P$. strombi without the normal array of introvert hooks and having a more massive ventral retractor muscle. We are tempted to reduce this to the status of a subspecies but at this time shall take no formal action.

A neotype has been deposited at the National Science Museum, Tokyo, and a paraneotype at the National Museum of Natural History, Washington, D.C. 


\section{Phascolion dentalicolum}

Phascolion dentalicola Sato, 1937a: 165-167, pl. 4, figs. 20-21, text-figs. 10-14; Cutler, 1977a: 145; Murina, 1978: 124.

Type Material: Many specimens dredged from $23 \mathrm{~m}$ from Onagawa Bay and living in Dentalium shells.

Material Examined: Tohoku University, Sendai, cat. \#8-32: 6 specimens from Mutsu Bay from gastropod and scaphopod shells overgrown by solitary madreporian coral. In bottle labeled $P$. ikedai; 1 specimen from Suruga Bay, 90-101 m, in shell of Inquisator angulatus, collected by M. Horikoshi; 7 specimens collected by $\mathrm{K}$. Osanai from gastropod and scaphopod shells in Mutsu Bay; 6 specimens collected at $120-260 \mathrm{~m}$ in Sagami Bay by the Biological Laboratory, Imperial Household.

The one Suruga Bay worm measured $35 \times 4 \mathrm{~mm}$ with the introvert completely retracted. Sato's Mutsu Bay worms ranged in trunk length from 5-8 mm, the Imperial Household specimens were $10-15 \mathrm{~mm}$, and Osanai's were from 7-19 $\mathrm{mm}$ long. One of these latter had the introvert completely extended, being half the trunk length and bearing dark hooks and about 12 tentacles. Endoprocts are present on serveral individuals. We were unable to locate any of Sato's type material and did not collect from Onagawa Bay. The Fisheries School of Tohoku Univer-

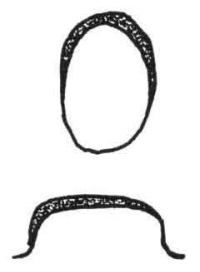

A

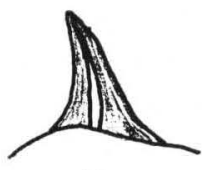

B

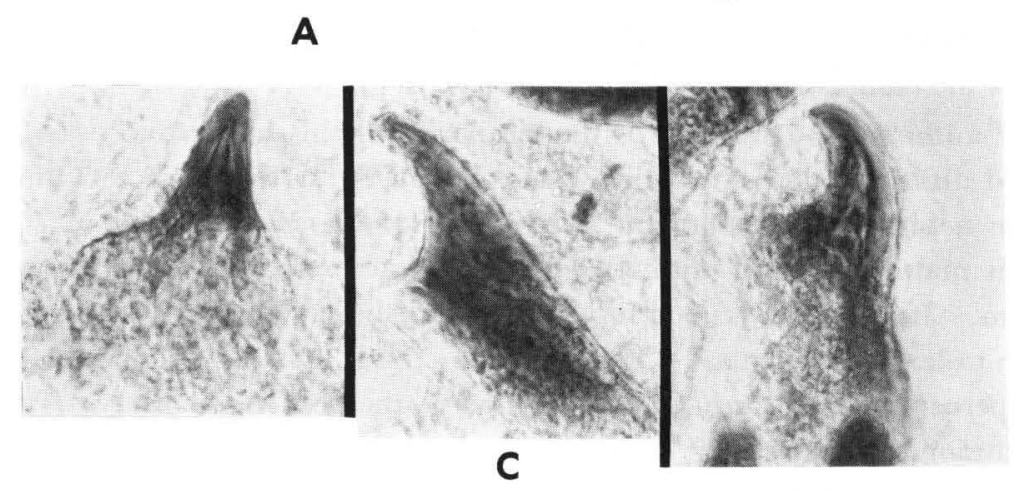

Figure 2. Phascolion dentalicolum.

A. Attachment papillae (holdfasts), after Sato, 1937a, text-fig. 11.

B. Introvert hook (after Sato, 1937a, text-fig. 13).

C. Photographs of three different introvert hooks at different orientations from a single individual. 
sity does have a laboratory there, so it should be possible for someone in the future to make new collections which would be helpful.

This species belongs to the group of Phascolion possessing hooks, holdfasts, and two retractor muscles of more or less equal size. The holdfasts have semicircular chitinous rims in most but in some this chitin encircles the papillae; they lack the tooth-like point (Fig. 2A). The shape of the hooks has been used to distinguish this species from others. However, they are not really sharply pointed as stated in the key of Stephen and Edmonds (1972:167) but rather bluntly pointed. As in other taxa there is variation in size and shape of these structures, but generally they are smaller than other related species and not as curved, with the tip rounded off. As shown in Fig. 2B \& $\mathrm{C}$ the apparent shape of these hooks, when viewed with a compound microscope, is heavily dependent on the orientation of the hook on the slide.

These 21 worms do fit this description in most important ways. We are designating a neotype from the new Mutsu Bay material and have deposited it at the National Science Museum, Tokyo, with a paraneotype at the National Museum of Natural History, Washington, D.C. The old Mutsu Bay specimens are preserved at Tohoku University, Sendai.

\section{Phascolion ikedai}

Phascolion ikedai Sato, 1930: 20-23, pl. 3, figs. 13-17, text-figs. 6-9; 1937a: 163-165, pl. 4, figs. 18-19, text-fig. 9.

Type Material: Many specimens from muddy bottom at 30 fathoms in Mutsu Bay. Material Examined: Tohoku University, Sendai, cat. \# 8-32 collected July, 1930 from Mutsu Bay. This is not type material although identified by Sato it was still in the shells ( 3 scaphopod, 1 gastropod) overgrown by a solitary madreporian coral.

These four worms are small (about 4-7 mm long) and not well preserved. The internal organs have deteriorated so it is impossible to verify Sato's comments about absence of rectal caecum or location of nephridium well in front of anus.

Externally these worms look very similar to $P$. strombi with the same array of tentacles, hooks (which Sato called spines), and holdfasts with anterior teeth. The primary difference seems to be the nature of the retractor muscles. Sato described this as being a single muscle with two short roots. Because of the poor condition of the specimens we could not be positive but in one worm it appeared to have either two long roots or perhaps was two muscles which fused. Fresh material is needed to verify this condition but recent collections by biologists in Mutsu Bay have not included any of these worms. The only other comment we can make is that Sato said the holdfasts are on the anterior one third of the trunk, but we found them to be on the posterior region of the trunk.

There is one error in Stephen and Edmonds (1972:179) where they fail to note Sato's (1937a) amendment of this species. He first said it lacked tentacles, which 
they repeat here and in the key, but in fact tentacles are present. We are not suggesting any change in the status of this species but are not completely comfortable with it.

\section{Phascolion rectum}

Phascoiion rectus Ikeda, 1904: 15-18, figs. 45-49.

Type Material: One specimen from Dentalium shell at $650 \mathrm{~m}$ in Sagami Bay.

Material Examined: 17 specimens from Misaki, 30-90 m collected by Cutler; 9 specimens from the Biological Laboratory, Imperial Household, collected at $80-250 \mathrm{~m}$ in Sagami Bay; three dubious specimens from Suruga Bay, 28-185 m, collected by Horikoshi and Kosaka; 1 specimen collected by Hayashi at $120 \mathrm{~m}$ in Wakasa Bay.

Ikeda's type specimen could not be found but these 30 specimens seem to fit his description in most ways. This species is in that group of Phascolion which lack both hooks and attachment papillae (holdfasts) and have only a single retractor muscle. It is distinguished from related forms by having its nephridium just posterior to the anus and free from the body wall. Our worms showed these traits but the retractor muscle sometimes appeared to have a single root rather than the two roots Ikeda described. Ikeda's worm measured $35 \mathrm{~mm}$, one third of that being a partially retracted introvert while in this material the introvert length is from 1.5-4 times the trunk length. Many of our specimens are dark and rather rough with dark papillae scattered over the surface, sometimes arranged in irregular longitudinal rows. The intestine is both looped and coiled as Ikeda noted.

This species is a reasonably distinctive form and we have deposited a neotype at the National Science Museum, Tokyo and a paraneotype at the National Museum of Natural History, Washington, D.C.

\section{Themiste elliptica}

Dendrostoma ellipticum Sato, 1934: 20-22, pl. 1, fig. 10, text-figs. 22-25.

Type Material: One specimen from $34^{\circ} 44^{\prime} \mathrm{N}, 138^{\circ} 30^{\prime} \mathrm{E}$ in Suruga Bay, $51 \mathrm{~m}$. Material Examined: None.

Numerous sipunculans were examined from subtidal areas near the type locality but no member of this genus was seen. In Stephen and Edmonds (1972:194) this is placed in their Group 5 along with T. fisheri and T. dehamata which also have the nephridia posterior to the anus, short contractile tubules, long cylindrical trunks, and which lack hooks. Themiste fisheri Amor is described as having six tentacular stems (not four as in the other two). It should be noted that Amor's (1964) description was based on a single individual whose introvert is retracted making it 
very difficult to clearly ascertain the tentacular arrangement.

When Sato described this species he compared it to $T$. dehamata (along with others) but pointed to the difference in papillae shape (elliptical vs round) as significant. In our view, it is not difficult for a glandular structure like this to change from round to elliptical or vice versa.

Without making any formal proposals we would simply suggest that the differences between these three forms are minimal at best and their biological significance is questionable.

\section{Themiste hexadactyla}

Dendrostoma hexadactylum Sato, 1930: 28-33, pl. 4, figs. 20-24, text-figs. 13-15; 1937a: 162-163, pl. 4, fig. 17; Okuda, 1946: 224, pl. 29E.

Dendrostomum hexadactylum: Fisher, 1952: 410-411, pl. 30, fig. 2.

Type Material: Many collected in Mutsu Bay.

Material Examined: Specimens identified by Sato, including type specimen at Tohoku University, Cat. \#1-4, 1-5, 2-2, 4-11, 5-11, 5-15, and G 26. 2 specimens from Akkeshi, Mar. Lab, University of Hokkaido.

Sato's careful and detailed original description requires no comment. His additional records (1937) expanded the geographical and size range for this species. The records from Hokkaido along with that of Okuda (1946) extend its range to the north and Fisher's California records show it to be on both sides of the North Pacific.

The principal (only?) feature distinguishing this form from T. blanda is the number of tentacular stems (six vs four). When examining Sato's material, especially the larger forms, it became very difficult to discern the exact number of stems because of the complex nature of the array. In smaller animals with fewer subdivisions and less complex systems, the presence of six main branches can usually be seen. This is almost impossible to see when the introvert is retracted as is often the case. Depending on one's perspective there can be four, five, or six stems.

The type specimen (G 26) is in very poor condition but others from the same place (especially \# 4-11) are in excellent condition and useful for comparisons. We would hereby designate catalogue $\$ 4-11$ as paralectotypes. Sample \#1-4 contains the very large specimens Sato refers to in 1937.

\section{Themiste minor}

Dendrostoma minor Ikeda, 1904: 57-59, figs. 16, 92-95; Stephen, 1942: 252: Chin, 1947: 100.

Dendrostomum minor: Wesenberg-Lund, 1963: 128-129; Stephen and Cutler, 1969: 116;

Themiste minor: Cutler, 1977a: 147; Cutler \& Cutler, 1979: 967.

Type Material: Many specimens found under algae covering rocks along the tide 
marks in Funakawa, Misaki, Habu on Izu-Oshima, and Tanegashima.

Material Examined: At the University of Tokyo: 5 specimens identified by Ikeda (apparently type material) and 3 specimens identified by us as this species.

Collected by Cutler: 33 specimens from Mukaishima Mar. Stat., Onomichi-City; 3 specimens from near Misaki.

Ikeda found this species at several widely separated locations but Sato never reported finding any. This name has appeared in the literature elsewhere and seems to be a valid species. The specimens we collected range in trunk length from 4-11 mm, most being around 7-8 mm; are yellow to tan with darker color at both ends of the trunk. The introvert is about one third the trunk length and bears hooks which vary widely in number, pigmentation, chitinization and pointedness. The color of the tentacles and oral disk varies from white to violet which, while living, gave the impression of more than one species. There are four tentacular stems, each divides into two and each of these has 4-6 tentacles. With retracted introverts this is very difficult to discern. The two retractor muscles originate in the middle of the trunk. The nephridia open at, or just posterior to, the level of the anus, about 1/3-1/2 the trunk length, and are unattached to the body wall. The rectum bears a caecum.

This species is closely related to T. huttoni and T. fusca. One supposed difference is whether or not the contractile vessel villi branch. A close inspection of these villi from several worms was made by removing a section of the esophagus bearing the contractile vessel. The form of the villi is often club-shaped with a bulbous swelling near the tip and the size increases towards the intestinal coil. Of particular interest is the fact that about $5-10 \%$ of the villi exhibited a branching pattern, usually two but sometimes three irregular branches off the primary stem. This was seen in worms ranging in length from 5-11 $\mathrm{mm}$ with the larger worms showing a very slight increase in frequency and complexity of branching. This pattern could very easily be overlooked.

The five specimens of Ikeda's may have been his type material. At some time in the past, however, they have completely dried out and are now shadows on the bottom of the jar. In view of this, specimens from our Sta. 8 are designated as neotype and paraneotype. The neotype is deposited at the National Science Museum, Tokyo, and the paraneotype at the National Museum of Natural History, Washington, D.C.

\section{Themiste tropica}

Dendrostoma tropicum Sato, 1935: 313-315, pl. 4, fig. 15, text-fig. 11.

Dendrostomum tropicum: Wesenberg-Lund, 1963: 131-132.

Themiste tropica: Cutler, 1977b: 154.

Type Material: One specimen collected from Takegen, Yap Island. 
Material Examined: None.

The single specimen from Yap Island can not be located. Other authors have commented on the lack of clarity within this genus. Wesenberg-Lund's 1963 redescription of this species as well as Fisher's key $(1952: 405)$ contribute to this condition.

Fisher boldly asserts that $T$. tropica has four tentacular stems even though Sato made no mention of tentacles at all. Wesenberg-Lund had three worms from South Africa to which she applied this name despite: A. presence of papillae on the introvert while Sato clearly said there were none. B. retractor muscles with origins in the midtrunk instead of the posterior quarter, and C. very short vs very long nephridia. Another confusion factor is that in her text Wesenberg-Lund says some of the contractile vessel villi are branched but in the key she says they are unbranched. Wesenberg-Lund also suggests that $T$. tropica may well be identical with $T$. elliptica (Sato) but keeps them separate. Our reading of the descriptions leads us to the same conclusion as Wesenberg-Lund but without comparative material will herein simply point to these above mentioned problems and hope that at some future time this issue can be more satisfactorily resolved, perhaps by making collections in Yap.

Cutler (1977b) described 56 specimens from one station off Mombasa as this species. They closely resembled Wesenberg-Lund's redescription in having retractor muscles at about $60 \%$, papillae on the introvert, and the nephridia about $20 \%$ of the trunk length. They also have four distinct tentacular stems and skin papillae which are round, each pore seemingly set in a rectangle caused by the reticulation of the skin.

\section{Aspidosiphon (Aspidosiphon) carolinus}

Aspidosiphon carolinus Sato, 1935: 318-319, pl. 4, fig. 19, text-figs. 16-17.

Type Material: Four specimens collected from Arakoron, Palau, West Caroline Islands.

Material Examined: None.

The four worms Sato used as the basis for this species cannot be located. On Ponape (East Caroline Islands) we collected 10 members of this subgenus and on Majuro (Marshall Islands) 25 specimens, but they were all A. elegans. Sato's were all very small (he mentioned the exact size of only one, $4 \mathrm{~mm}$ ) and were collected along with several specimens of a new variety of $A$. elegans var. yapense. This latter form was larger $(23 \mathrm{~mm})$ and differed from the nominate form in the shape of the hook. In Sato' key $(1939: 320)$ these two species come out next to each other and are separated by their trunk size, hook size and curvature, and number of hook rings. A small $A$. carolinus has smaller and fewer and less sharply bent hooks but in all other characters is identical to $A$. elegans. The fact that the number of hook rings varies with age has been commented on by many authors. In a subsample of 25 out of our $201 \mathrm{~A}$. elegans we found a range of 7-40 complete rings of hooks (in 
worms $6-37 \mathrm{~mm}$ long). Generally the smaller worms have the fewest number but in the larger worms there is a wide range of values, perhaps due to differential wearing off with use. That hook size increases with trunk size is also well documented (Cutler, 1965; Cutler and Cutler, 1980).

There is no doubt in our minds that $A$. carolinus represents nothing more than four small $A$. elegans and should, therefore, be treated as a junior synonym.

\section{Aspidosiphon (Aspidosiphon) misakiensis}

Aspidosiphon misakiensis Ikeda, 1904: 41-43, figs. 9, 68-72.

Type material: Several young and adult specimens from the rocky shore at Misaki Marine Laboratory.

Material Examined: Collector

Area

\# of Individuals

\begin{tabular}{llr} 
Cutler & Misaki/Miyakejima/Tateyama & 17 \\
\multirow{2}{*}{ Nishikawa } & Katura, Kagoshima & 1 \\
& Tottori, Japan Sea & 4 \\
Imajima & Wakayama Pref. & 8 \\
& Tsushima Island & 1 \\
& Ogasawara Islands & 1 \\
Ikeda & Shionomisaki & 8 \\
& $?$ & 1
\end{tabular}

These 43 specimens are small, most around $10 \mathrm{~mm}$, but range in trunk length from 3-18 mm. Most lived in soft rock in the intertidal zone. More precise station data will appear in a later paper. The one specimen from Ikeda's collections was found in a bottle of Phascolosoma and was not identified by him. These worms agree well with Ikeda's original description with the following exceptions.

It is difficult to accurately measure introvert length but many appear to be less than three times as long as the trunk. The anal shield is dark brown but we would not use the word 'minute' to describe the size of the component granules (Fig. 3A). They are of moderate and varying size. The caudal shield is not always dark brown but may be pale tan. Ikeda said the nephridia are about $2 / 3$ as long as the trunk, but we found them to vary in size from 50-100\% of the trunk length. He also stated that these organs were attached to the body wall for their entire length. While we found this to be true for some animals, others have nephridia fixed for only 50 or $75 \%$ of their length.

Three internal features were consistant and helpful for identification. The intestinal coil is irregular and loose, the two retractor muscles have their origins very close to the caudal shield, and the longitudinal musculature exhibits the intermediate condition, being continuous but having fractures especially on the dorsal side giving the appearance of frequently anastomosing bundles (as noted by Ikeda).

The concept of introvert spines is discussed elsewhere ( $A$. makoense/formosanus) and for this species Ikeda is referring to pale, gently curved structures we would 


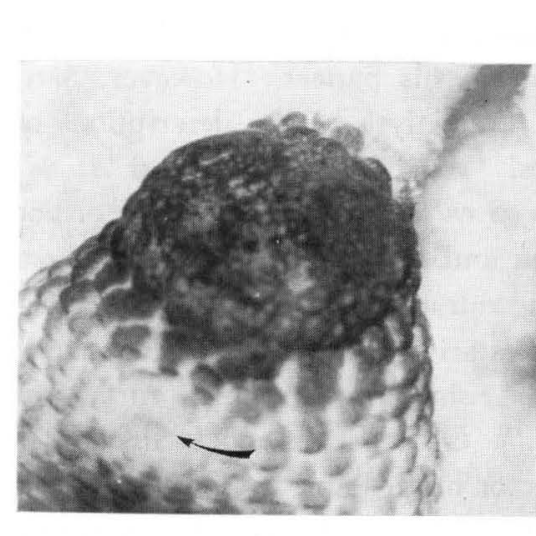

A

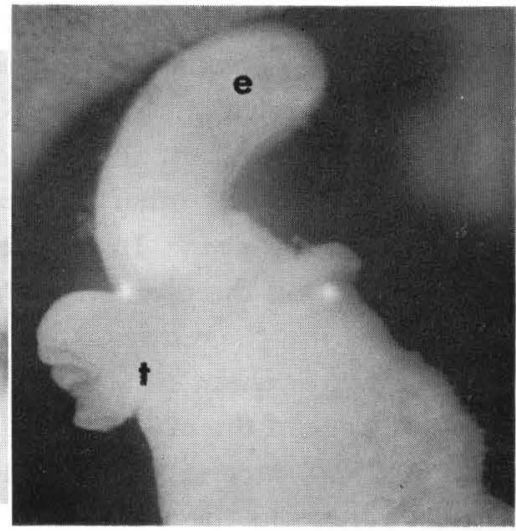

B

Figure 3. Aspidosiphon misakiensis.

A. Anal shield (arrow pointing to anus).

B. Esophagus protruding through mouth showing dorsal arrangement of tentacles (not circumoral). (t-tentacles, e-esophagus)

C. Introvert hook (after Ikeda, 1904, Pl. III, fig. 70).

otherwise call single-pointed or unidentate hooks (Fig. 3C). Sato (1939:450) separated this species from others in his key by stating that the spines are of uniform dimensions. Our observations do not concur as we found spines ranging in size from $0.025-0.06 \mathrm{~mm}$, not just $0.045 \mathrm{~mm}$ as Ikeda stated. The bidentate hooks range in size from $0.03-0.04 \mathrm{~mm}$.

One interesting feature of this collection is the number of animals we managed to preserve with their introverts completely extended, several having the esophagus protruding through the mouth (Fig. 3B). This is additional data to reinforce the fact that in this genus the tentacles do not surround the mouth as stated in some literature (e.g. Stephen and Edmonds, 1972) but are arranged dorsal to it as in Phascolosoma and a few Golfingia (Cutler, 1979).

A neotype and paraneotypes were selected from collections made by us one kilometer north of Tateyama Marine Laboratory, Boso Peninsula and have been deposited at the National Science Museum, Tokyo, and the National Museum of Natural History, Washington, D.C.

\section{Aspidosiphon (Aspidosiphon) spinalis}

Aspidosiphon spinalis Ikeda, 1904: 47-49, figs. 12, 81-85; 1924: 37.

(Not Aspidosiphon spinalts: Cutler, 1973: 175-176.)

Type Material: Numerous specimens from dead coral at Koniya, Amami-Oshima Island.

Material Examined: None.

We could find none of Ikeda's material. We made collections from dead coral 
near Koniya (the type locality) and found 47 examples of what we consider to be $A$. elegans. Ikeda never used the name A. elegans in his papers. However, Sato used $A$. elegans but never recorded A. spinalis. Our analysis of the descriptions of these two species reveals no significant differences. When Ikeda described A. spinalis he made no comparisons to any other species so we do not know whether or not he mentally compared it to A. elegans. In Stephen and Edmonds (1972: 219) these two species are differentiated on the position of the retractor muscle origins. Ikeda (1904:49) says about $A$. spinalis, "...retractor muscles arise just in front of the caudal shield." Sato (1939:427) says about A. elegans, "...rising from the inner surface of the body wall slightly in front of the caudal shield." Other statements in the literature on $A$. elegans are not very precise about retractor origins and we found a range from $70-90 \%$ of the distance to the posterior end of the trunk in our specimens. Our experience with other species suggests that this feature does vary within a population and by itself is insufficient grounds for species separation.

We conclude that $A$. spinalis is a junior synonym of $A$. elegans. One problem remains i.e., the use of the name $A$. spinalis by Cutler (1973). It is now clear to us that our earlier concept of this species was faulty. The main confusion factor was the concept of a spine. This word is used in two very different ways when discussing Asidosiphon. It has different meanings in other genera. In this context the term has been used to mean the large dark brown structures described by Ikeda (1904:48) as being "... formed by a thin chitinous lamina folded in a funnel like manner;..." Their size and density are variable but depending on the orientation of the structure on a microscope slide the shape may appear straight and conical or as a gently curved hooklike form. This is evidently due to its three dimensional shape, and when viewed from the side it has a curved outline which is not seen when viewed from the front or back (Fig. 4C).

On the other hand the term spine has been used by Ikeda, Sato and others to

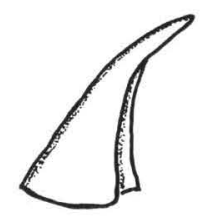

A

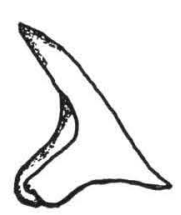

B

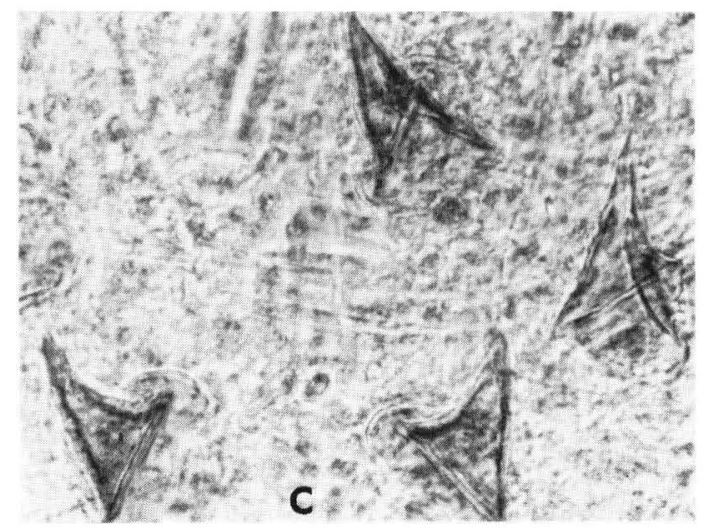

Figure 4. Aspidosishon spines/hooks.

A. from A. formosanus (after Sato, 1939, text-fig. 56a).

B. from A. grandis (after Sato, 1939, text-fig. 49b).

C. Photograph of A. elegans introvert spines showing variation in appearance dependent on orientation. 
refer to small, unpigmented, gently curved, single-pointed hooks as in A. misakiensis. A good example of this unclarity can be found in Sato (1939) where on page 422 he illustrates spines of $A$. formosanus and on page 417 he shows hooks from $A$. grandis which look very similar (Fig. 4A, B). One further example of confusing word usage is seen in Sato's same paper on page 403 where he is describing Golfingia vulgaris and figures what he calls spines but which all others call hooks.

In other words, when one sees the word spine in the writings of Ikeda and Sato, one must be careful. This failure on the part of E. Cutler several years ago led him to incorrectly use the name $A$. spinalis for what now appears to be a yet unnamed species.*

\section{Aspidosiphon (Paraspidosiphon) angulatus}

Aspidosiphon angulatus Ikeda, 1904: 45-47, figs. 11, 78-80; 1924: 37; Cutler and Cutler, 1979: 974.

Type Material: One specimen from low water at Katsuyoki Inlet, Amami-Oshima Island.

Material Examined: None.

We collected 97 examples of this genus from Amami-Oshima, but nothing resembled this species. All of those with longitudinal muscle bands (subgenus Paraspidosiphon) were Aspidosiphon steenstrupii which has a granular, ungrooved anal shield and bidentate hooks.

There are three species with only single pointed hooks which are very similar to this one. Aspidosiphon trinidensis differs in having the retractor origins much closer to the caudal shicld and an ungrooved anal shield. Aspidosiphon cumingii and $A$. klunzingeri are similar in all ways except their rectum bears an array of caecae or diverticula.

Cutler and Cutler (1979) described 18 specimens from Moorea, French Polynesia and one from Tulear, Madagascar, as this taxon because they matched Ikeda's description well. Minor differences were introvert length (ours being longer than the trunk instead of the same length); retractor muscle origins (ours in the third quarter as opposed to just behind the middle); and nephridia length (ours about one-half the trunk not one-third). However, this species has not been found by Sato, Edmonds, or others working in nearby areas since 1924 so it is not a common species.

\section{Aspidosiphon (Paraspidosiphon) formosanus}

Aspidosiphon formosanus Sato, 1939: 421-424, pl. 21, fig. 23, text-figs. 55-57; Edmonds, 1971: 144-146.

Type Material: Two specimens from coral rock at Sinko, Formosa.

Material Examined: Forty-four specimens identified by Edmonds from Guam.

* This form will be named A. gosnoldi in Cutler, E.B., 1981, Proc. Biol. Soc. Wash. (in press). 


\section{Aspidosiphon (Paraspidosiphon) makoensis}

Aspidosiphon makoensis Sato, 1939: 419-421, pl. 21, fig. 22, text-figs. 51-54.

Type Material: Three specimens from dead coral at low tide at Mako, Formosa. Material Examined: None.

When Sato described these two species from Formosa he also recorded A. steenstrupii. These three species are very similar morphologically and ecologically. Sato had two examples of $A$. formosanus, three of $A$. makoensis, and numerous $A$. steenstrupii. We have examined over 300 specimens which we believe to be $A$. steenstrupii from Japan, Guam, and the East Caroline Islands.

Sato (1939:424) maintained that A. makoensis differed from $A$. formosanus by "features of the retractor muscles and of the skin papillae found in the middle region of the trunk." He is referring in the first case to his statement that in A. makoensis the two muscles are fused for the greater part of their length. He says nothing in the text about fusion in $A$. formosanus but refers one to his text-figure 57 which shows them separate for much of their length. He uses this feature in his key on page 449 to distinguish the two species. Both of these reportedly have their origins just in front of the caudal shield while $A$. steenstrupii has its retractor origins about $75 \%$ of the distance to the posterior end of the trunk according to Selenka et al (1883). The language again creates problems here because it is often vague and imprecise. Many authors make no mention of this trait while others use phrases like "some distance in front", "just in front", "in the last quarter", "at the beginning of the last quarter", etc. when describing $A$. steensirupii. In the recently collected specimens, we found the retractor muscles have their origins anywhere between 75 and $95 \%$ of the distance to the posterior end of the trunk, most being around $80-85 \%$. The matter of fusion/separation of the two retractor muscles is dependent on the degree of extension/contraction of the introvert. In any species, as the introvert is extended, the muscles stretch and give the appearance of being more separate from each other, within certain limits. For example, in our recent collections, we found a separation from $25-40 \%$ of the muscles within the trunk in extended animals and from 12 $22 \%$ in contracted forms. On the basis of our observations there is reason to doubt the meaningfulness of this trait or to weight it very heavily. We have elsewhere discussed our views on Sato's use of skin papillae as species specific characters and here would again suggest that the alleged differences have minimal importance. One other presumed difference is brought out in Stephen and Edmonds (1972: 239) key to this subgenus which is where the nephridia are or are not completely fastened to the body wall. Aspidosiphon makoensis is described as being attached for their whole length while in $A$. formosanus they are fixed for only half their length, as is the case in $A$. steenstrupii. We found no specimens with their nephridia completely attached nor did Edmonds (1971) in the material from Guam which he identified as $A$. formosanus. This attachment is quite fragile, easily torn, and rarely constant in a population. 
Edmonds (1971) is the only author to make reference to these species since 1939. He had 41 specimens from Guam and three from Palau. We examined his material and collected more of the same type from Pago Bay, Guam, and Ponape, in the East Caroline Islands. Edmonds points to the similarities of these species under discussion and by using the form of the internal 'clear streak' of the bidentate hooks he removed $A$. steenstrupii from the discussion. This feature has been used taxonomically in the genus Phascolosoma but never before for Aspidosiphon. While it may have usefulness, there is a strong risk of oversimplifying and ignoring the variation within a population or within an individual's population of hooks. If one looks only at the figures in Sato and Selenka, there appears to be a difference. However, if one takes a series of hooks from a few worms in one population one sees variation in size and shape of the hook and the aspects of the internal clear area which encompasses the variation found in the aforementioned figures.

We have published and unpublished records of $A$. steenstrupii from several localities in which variations in shields and papillae are evident. In our opinion, these are no more meaningful than racial differences in mammalian species and we hereby propose that $A$. makoensis, $A$. formosanus, and $A$. steenstrupii are synonyms. Aspidosiphon steenstrupii being the senior name should remain and include in this common circumtropical taxon Sato's five and Edmond's 44 worms.

\section{Aspidosiphon (Paraspidosiphon) grandis}

Aspidosiphon grandis Sato, 1939: 414-419, pl. 21, fig. 21, text-figs. 46-50.

Type Material: One specimen from Daihanratu, Formosa.

Material Examined: Sato's type specimen at Tohoku University $\# 24$.

This single, large specimen is in beautiful condition and in all ways agrees with Sato's detailed description. The one point we would make about its anatomy is with reference to the retractor muscle. As with other species when the introvert is completely drawn in, the retractor muscles appear much shorter and stouter than otherwise. If this animal had its introvert extended, we are sure it would be described as having a pair of retractor muscles which fuse to form a single muscle at some distance from the posterior end of the trunk.

Aside from the above, a more important point concerns the validity of this species. Sato (1939:419) noted, "...Aspidosiphon cumingii closely resembles the present new species both in general form and in the internal anatomy. It may be however, distinguished from this new species by the features of the skin papillae as well as by the number of hook-rows." Aspidosiphon cumingii has been reported as having up to 230 rows of hooks but many authors have noted the fact that this number is variable with age of the worm. It is possible that this larger, older animal has lost some of the rows of hooks it bore at an earlier time, having only 60 now. At any rate, this character is not species specific. His second point about papillae is likewise difficult to accept as anything other than what would be typical for a large 
specimen of $A$. cumingii. It is impossible for us to see any significant differences between these two forms. We suggest that they be considered as one. Aspidosiphon cumingii has been reported from the Philippines and Malaysia, not far from Formosa, so that from a zoogeographical perspective this merger is also conceivable.

\section{Lithacrosiphon uniscutatus}

Aspidosiphon uniscutatus Ikeda, 1904: 43-45, fig. 10, pl. 3, figs. 73-77; 1924: 37-38.

Lithacrosiphon uniscutatus: Sato, 1939: 429.

Type Material: One specimen taken from dead coral at Kataura, Kagoshima Prefecture.

Material Examined: None.

A total of 96 members of this genus was collected from Okinawa, Amami-Oshima, Majuro, Ponape, and Guam but none fit the description of this species. Two collected from Kabira Bay were badly damaged and small but the trunk lengths of the others range from 8-25 mm, with one from Guam being $38 \mathrm{~mm}$ long. These worms match the description given by Ikeda in all ways except one critical feature: there are up to 25 rings of bidentate hooks near the distal end of the introvert (Fig. 5).

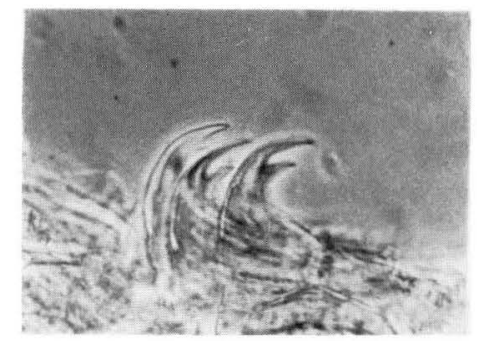

Figure 5. Distal bidentate introvert hooks from Lithacrosiphon.

This genus was revised by Cutler and Jurczak (1975) and the number of species reduced to three: L. cristatus, L. maldivensis, and L. uniscutatus. L. maldivensis is distinct because of its anal shield but the other two could only be separated on the basis of the bidentate hooks being absent in L. uniscutatus. This taxon was defined to also include $L$. kukenthali and L. poritidis. In that paper it was noted, "This alleged absence of bidentate hooks may be the result of incomplete introverts or oversight on the part of the observer. ...However, as the type of $L$. uniscutatus cannot be found and the single specimens of $L$. kukenthali and $L$. poritidis are presently without introverts, we can neither confirm nor deny this condition. Our concern stems from our discovery that several mistakes were made by workers on this genus with respect to the nature of the hooks. The possibility exists that the same problem is at hand here."

The following facts should be considered:

1. In the intervening 80 years several hundred sipunculans have been collected 
by Sato, myself (collections made at the type locality on April 10, 1979, from dead coral rock and sandstone), and others from nearby areas but no worm fitting Ikeda's description has been found.

2. Specimens fitting his description in all ways except the hooks have been found on nearby islands.

3. As pointed out in Cutler and Jurczak (1975) several other authors overlooked the presence of bidentate hooks. Also sometimes the second tooth is worn or broken off on certain rows of hooks.

These facts, in our mind, greatly weaken the probability that such a species actually exists. It is proposed, therefore, that L. uniscutatus be reduced to the status of a junior synonym of $L$. cristatus (Sluiter). If any future collections contain truly unidentated specimens, then this name could be resurrected.

\section{Phascolosoma (Rueppellisoma) nahaense}

Phymosoma nahaense Ikeda, 1904: 29-31, figs. 8, 59-62.

Type Material: Two specimens collected from dead coral masses at Naha (Naminouye), Okinawa.

Material Examined: None.

In Ikeda's first paragraph of this description, he made the observation that "in external features they closely resemble $P$. scolops for which species they were at first mistaken by me". The two worms he based this species on differed from P. scolops in only one character i.e., "The retractor muscles are represented by the ventral pair only, the dorsal pair being wanting." This fact caused him to compare it only to $P$. rueppellii, also with two retractor muscles but with which there are some obvious differences. It now resides in the subgenus Rueppellisoma, so very rarely gets compared to $P$. scolops with which it seems identical in all ways except one.

One species which looks very similar to $P$. scolops except for hook structure is $P$. albolineatum. A population of these from Diego Garcia (Indian Ocean) was described in Cutler and Cutler (1979) in which two, three, and four retractor muscles were present. Of special interest here is some work done by Gibbs (1973) with three populations of Golfingia elongata in England. That species is described as having four retractor muscles but in his examination of over 300 worms, he found from 13-15\% having only two or sometimes three muscles (29/343 with only two). Gibbs cites other examples in the literature where similar abnormalities of retractor muscles have been recorded. It is very likely that this is an ontogenetic anomaly where the dorsal and ventral muscle fuse or where the dorsal muscle simply does not develop.

We collected 355 sipunculans on Okinawa. Of these, 118 belong to this genus; 41 were $P$. albolineatum and one was $P$. scolops, but none had only two retractor muscles. Also, in the collections others have made near the type locality over the years there have been no records of $P$. nahaense. 
In light of the above, it seems most probable to us that the two worms described by Ikeda as $P$. nahaense represent nothing more than abberant individuals within the large population of $P$. scolops and the taxon should, therefore, be treated as a junior synonym.

\section{Phascolosoma (Rueppellisoma) onomichianum}

Phymosoma onomichianum Ikeda, 1904: 26-28, figs. 7, 56-58.

Physcosoma onomichianum: Sato, 1934: 247; 1939: 397-398, pl. 22, fig. 14, pl. 23, fig. 43.

Phascolosoma onomichianum: Wesenberg-Lund, 1959: 67; 1963: 127-128; Murina, 1967b: 44.

Type Material: One specimen from a collection made in 1901 in the inlet of Onomichi, Province of Bingo (now Hiroshima).

Material Examined: One specimen identified by Ikeda from Itoman, Okinawajima at University of Tokyo.

Many specimens at Tohoku University, Sendai, cat. $2-15$, 2-21, 2-28, 3-5, 7-24, 8-13, 8-15; identified by Sato.

Eight specimens from the intertidal zone near the Mukaishima Marine Biological Station, Onomichi-shi.

The eight specimens we collected with Dr. Inaba's help have the following measurements in the preserved state:

$\begin{array}{cccc}\begin{array}{c}\text { trunk } \\ \text { length }\end{array} & \begin{array}{c}\text { trunk } \\ \text { diameter }\end{array} & \begin{array}{c}\text { introvert } \\ \text { length }\end{array} & \begin{array}{c}\text { number of } \\ \text { tentacles } \\ 30\end{array} \\ 6 & 10 & 200+ \\ 28 & 6 & 10 & \\ 17 & 3 & 8 & 100 \\ 17 & 3 & 6-7 & \\ 15 & 3 & & \\ 15 & 4 & 8 & 30 \\ 12 & 4 & 8 & \\ 6 & & 4 & \end{array}$

We were able to spend some time observing these worms during the relaxing/ preservation period and our observations about introvert length is noteworthy. In the living state all sipunculans have a very plastic form which can be stretched, twisted, and contorted in many ways. There is no constant ratio between introvert and trunk length even with the tentacles out. After a period of exposure to menthol crystals and a small amount of alcohol, these worms were placed in $70 \%$ ethyl alcohol. Most did not pull their tentacles in but several shortened the introvert so it appears to be only $1 / 3$ the trunk length with the tentacles still out and not the $2 / 3-3 / 4$ as it was earlier.

The number of tentacles varies with the age/size of the worm as in other species (see above). They are arranged generally in the typical phascolosomatid fashion i.e., a crescent around the nuchal organ and dorsal to the mouth, not surrounding 


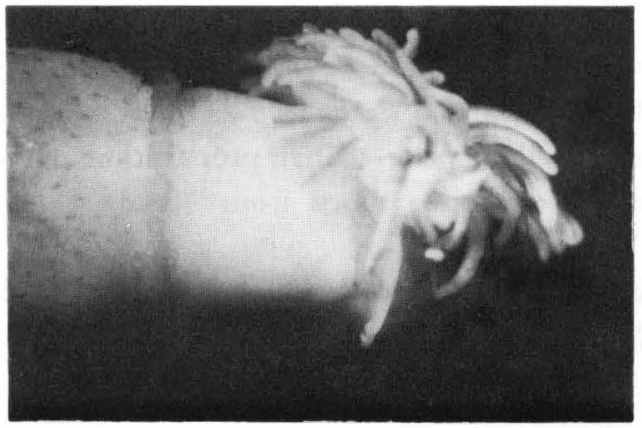

Figure 6. Tentacular crown from Phascolosoma onomichianum.

the mouth as Ikeda stated (Fig. 6). The tentacles have a violet pigmentation, some with longitudinal stripes and others with the pigment in patches or bands around the tentacles. This pigment continues onto the surface around the nuchal organ. Behind the tentacles is a smooth, white region followed by the fleshy collar.

The contractile vessel bears numerous conspicuous villi, the longer ones bifurcating or branching dendritically. These are present along the entire length of the vessel, shorter ones toward the head region. The nephridia open just behind the anus, are about $40-50 \%$ of the trunk length and attached for $80-90 \%$ of their length to the body wall by a well defined mesenteric sheet. The one pair of retractor muscles attach about $65 \%$ of the distance to the posterior end of the trunk. Each of the muscles is subdivided near its origin from the trunk wall into two short roots. In some, these roots are again subdivided so that there is almost a separate root for each longitudinal muscle band it is connected with. In general, it gives the impression of a worm in which the dorsal retractor muscle has fused with the ventral almost completely. The longitudinal muscles in the posterior third are very distinct, anastomose very much and number about 28-32. In the midsection of the trunk they become flattened, broad and very indistinct almost to the point of looking like a continuous sheet with occasional splits or fractures. A careful examination of the rectum shows a single bulbous caecum present in the first loose gut coil which is usually hidden by the contractile vessel villi. Ikeda's worm from Itoman has a $20 \mathrm{~mm}$ trunk and otherwise is as those above. Sato's specimens came from Korea and Formosa.

This species is distinctive as the only member of this genus in Japan with two retractors and no hooks. The dark, rough body and short introvert with many tentacles makes it easy to identify. However, as elsewhere, there exists a complex of three or four closely related species. In this subgenus there are two other hookless forms described from this part of the world: P. gaudens (Lanchester, 1905) from Malaya and P. simile (Chen and Yeh, 1958) from China. When Lanchester described his species he noted its close similarity to $P$. weldonii (Shipley, 1892) from the Bahamas. After examining these Japanese specimens, a comparison of the written descriptions of this group raises serious doubts about the distinctive differences. What is needed is a side by side comparison of specimens with the four 
names, if possible.

In 1959 Wesenberg-Lund reported $P$. onomichianum from Mauritius and in a confusing manner placed $P$. gaudens and $P$. weldonii as questionable synonyms. I assume that $P$. simile was not described prior to her preparation of that manuscript. She also reported $P$. onomichianum once more from Natal, South Africa (WesenbergLund, 1963).

A neotype has been deposited at the National Science Museum, Tokyo, and paraneotypes at the National Museum of Natural History, Washington, D.C.

\section{Phascolosoma (Phascolosoma) deani}

Phymosoma deani Ikeda, 1905: 171-172, pl. 8, figs. 5-8.

Type Material: Several from Manjuyodi, South Negros, the Philippines.

Material Examined: A vial found at the University of Tokyo Museum containing 8 specimens and labeled "Phymosoma deani n. sp. collected Feb. 1901, shallow water, South Negros, Manjuyodi; B. Dean. Believed to be type material.

The trunk lengths range from $17-33 \mathrm{~mm}$; most are about $20 \mathrm{~mm}$. One fully expanded worm has a $25 \mathrm{~mm}$ trunk and a $40 \mathrm{~mm}$ introvert. The most striking feature is the trunk papillae found on the anterior $20 \%$ and posterior $15 \%$ of the trunk. They are very dark, mammiform, and with sharp boundaries against the pale background. There are eight lobular tentacles followed by a fleshy, white collar. Internally the nephridia are about 50-60\% of the trunk length and attached for $90-95 \%$ of their length. The four retractors have a peculiar arrangement and look very different in expanded verses contracted specimens. In the expanded condition, the retractor muscles are quite separated, the two ventrals being very slender, originating from longitudinal muscle band 1 while about $0.5 \mathrm{~mm}$ posteriorad the broader dorsal pair arises most from bands 2 and 3 but also extends onto bands 1 and 4 . In the contracted state, it has the appearance of a single strong muscle with four roots. This issue of whether we have two muscles which fuse quickly or one muscle with two roots is a troublesome one in a number of species. I suspect it is partly due to the state of contraction of the particular worm being described.

This species is very distinctive and well described by Ikeda, but he failed to compare it to any existing species. However, it seemed to resemble Phascolosoma arcuatum (now including $P$. lurco) in many ways. $P$. arcuatum has been collected from several localities near the Philippines. Additionally the Chinese species $P$. esculenta (Chen and Yeh, 1958) is strikingly similar. A careful reading of the descriptions and comparison of illustrations showed no significant differences.

We subsequently sent a specimen to $\mathrm{S}$. Edmonds and his comparison with the Australian $P$. arcuatum led him to concur that the species are synonymous. The differences are slight and due to size and pigmentation. P. esculenta was reported by 
Murina (1964) from the South China Sea and she kindly sent us a few of those specimens. A side by side comparison of all three 'species' shows them to be clearly synonymous, having minor variations in retractor muscle origin and nephridia morphology. Therefore, we regretfully propose that both $P$. deani and $P$. esculenta be submerged under the senior synonym $P$. arcuatum.

A lectotype is deposited at the Zoology Museum, University of Tokyo, paralectotype at the National Science Museum, Tokyo, and reference material at the National Museum of Natural History, Washington, D.C.

\section{Phascolosoma (Phascolosoma) formosense}

Physcosoma formosense Sato, 1939: 398-401, pl. 20, fig. 15, text-figs. 36-41.

Type Material: Two specimens collected from Suo, Formosa.

Material Examined: None.

The two worms described by Sato cannot be located. His remarks suggest he saw a similarity to Phascolosoma japonicum but these differ "... in the number of hook rows and in the features of the skin papillae." This species may be a truly distinct form. If his description is accurate, it is the only Phascolosoma to have hooks that are not in rows (Sato says on page 399 that they are few and scattered). But in "Remarks", hook rows are mentioned (no number given). Sato's figure 41 appears out of proportion with the tentacles not completely extended. It is possible that the number of hook rows is small and they might be covered by a fold in the skin of a partially retracted introvert. The rest of the features of this form do fit the description of P. japonicum.

Nevertheless, despite the possibility of these two specimens being anomalous or inaccurately described $P$. japonicum, no suggestion is herein made for submerging this name as yet. If additional collections can be made at the type location in Formosa, this issue might be resolved more satisfactorily.

\section{Phascolosoma (Phascolosoma) glaucum}

Physcosoma glaucum Sato, 1930: 15-17, pl. 1, fig 6, pl. 2, fig. 7-8, text-fig. 4 .

Type Material: Two specimens from Urata, Mutsu Bay, Japan.

Material Examined: One type specimen at Tohoku University, cat. $\# 37$.

This single worm was not in good condition having evidently been at least partially dried out at some point during post mortum history. When Sato described this species he differentiated it on the basis of color and hook shape. When one compares the description of this species with $P$. japonicum (which is common in the type locality), these two differences are all that appear. When we examined the type specimen, it was a dirty brown color, not blue green as it appeared to Sato 40 years ago. The use of color as a species character is very risky in these worms as 
it can be easily influenced by microhabitat in life and by the type of preservative after death. The probability of any sipunculan being greenish blue is very small except as a result of some associated algae or mineral component of the sediment. We, therefore, doubt the meaningfulness of this trait.

Hook size and shape is more difficult. We removed a piece of tissue from the introvert of the type and can see, as in many species, a range of sizes and shapes. The shape can easily appear different due to the hook's particular orientation on the slide. Unless they all are laying uniformly flat, distortion can occur. Age and wear/use can also make a difference. While it is true that some hooks looked like Sato's text-fig 4, others (Fig. 7) matched perfectly his text-fig 2 of hooks from $P$. japonicum. The sharpness/bluntness of the apex does vary; it is not constant. In a later paper Sato (1937a:150) made the following statement about $P$. japonicum which is of particular interest in this context, "...there are some specimens which have the hooks on the introvert much smaller than those mentioned and figured by Selenka in 1883. The difference in size of the hooks, however, may not be assumed as an important characteristic to establish a distinct species but it may be looked upon merely as individual variation."

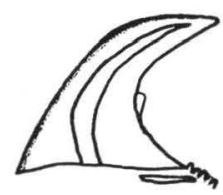

A

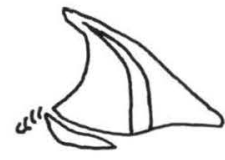

B

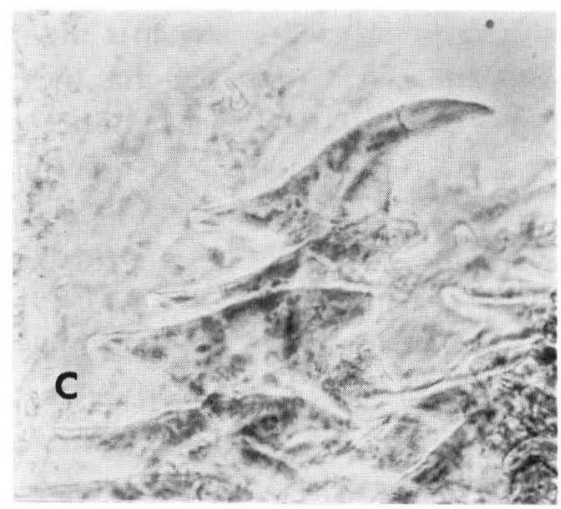

Figure 7. Hooks from Phascolosoma japonicum.

A. P. japonicum from Sato, 1930: 10, fig. 2.

B. P. glacucum from Sato, 1930: 16, fig. 4 .

C. Photograph of hooks from Sato's type specimen of $P$. glaucum.

There is an active marine laboratory on Mutsu Bay, the type locality, but no specimens of this type have been collected since the original find. Sato himself made extensive collections at other northern Honshu locations but never found additional specimens. He and others have collected numerous P. japonicum from that area.

In light of all the above it is our conclusion that $P$. glaucum is merely two individuals from the $P$. japonicum population which acquired a peculiar color and whose hooks may have been worn down or appeared different because of orientation under the microscope. Therefore, $P$. glaucum should be considered a junior synonym of P. japonicum. 


\section{Phascolosoma (Phascolosoma) kurilense}

Physcosoma kurilense Sato, 1937b: 117-120, text-figs. 1-4.

Type Material: Three specimens from Kurile Islands, Japan.

Material Examined: None.

Our search did not uncover Sato's three specimens nor did we discover such animals in other collections. Sato (1937b:120) stated: "This new species closely resembles Physcosoma japonicum (Grube) in the form of the hooks as well as in the general anatomy of the body. But the former is easily distinguished from the latter in the peculiar feature of the segmental organ..." This single feature became the basis for erecting a new species. His figure 4 illustrates this organ in addition to the text description. Unfortunately, very little collecting has been done in the Kurile Islands and even since the Russian occupation, no additional specimens have been discovered (Murina, 1977).

It is difficult to judge this matter but our experience suggests that the nephridia are especially plastic organs subject to great variation in shape, size, attachment, etc. and Golfingia murinae have secondary lobes of varying sizes. The anterior lobe in this form is indeed small. It is hard, given all of the other features it shares in common with $P$. japonicum to grant specific rank to these three worms. Our judgement would be that they probably share the same gene pool but may be a geographically semi-isolated population with one minor morphological variation, thereby, meriting a subspecific rank at best.

\section{Phascolosoma (Phascolosoma) yezoense}

Physcosoma yezoense Ikeda, 1924: 32-34, pl. 1, figs. 3-6.

Type Material: A number of specimens found under roots of marine algae at Oshoro, Hokkaido.

Material Examined: None.

This species was described by Ikeda and published after his death. The type material which was deposited at the Fisheries School, Sapporo, could not be located at the University of Hokkaido. This is another frustrating situation wherein we seem to have a small group of worms which are, in all ways but one, identical to a much more common population in the same region i.e., $P$. japonicum. The feature noted by Ikeda is the location of the ventral retractor muscles which he said arise near the posterior end of the body. In Sato (1939) this becomes in the key incorrectly transformed into"... attached to the posterior end." Despite active collecting on Hokkaido and in northern Honshu, no additional specimens have been subsequently collected and attributed to his species. While it is true that in most $P$. japonicum the ventral retractors originate in the third quarter of the trunk, it is reasonable to assume that one deme near the northern limit of the species range could exhibit this 
much variation and still be in the same species. Until new material can be collected, this taxon has no demonstrable foundation and should be considered a junior synonym of $P$. japonicum.

\section{REFERENCES}

Amor, A. 1964. El genero Dendrostomum (Sipunculida) en la Argentina. Physis 24 (68): 457-470. 1975. Notas sobre Sipuncula de la Argentina, Brasil y Peru. Physis 34 (88): 113-120.

Ghen, Y. and Yeh Cheng-chang. 1958. Notes on some gephrea of China with description of four new species. Acta. zool. sin. 10: 265-278.

Chin, T.G. 1947. Studies of Fukien Sipunculoidea. Biol. Bull. Fukien Christ. Univ. 3: 97-104. (In Chinese and English).

Cutler, E.B. 1965. Sipunculids of Madagascar. Extrait des cahiers ORSTOM-Oceanographie 3 (4): 51-63. 204.

1973. Sipuncula of the Western North Atlantic. Bull. Am. Mus. Nat. Hist. $152(3): 105-$

1977a. The bathyal and abyssal Sipuncula. Galathea Report 14: 135-156.

1977b. Shallow water sipunculans collected by the Galathea Expedition (Sipuncula). Steenstrupia 4: 151-155.

1979. A reconsideration of the Golfingia subgenera Fisherana Stephen, Mitosiphon Fisher, and Apionsoma Sluiter (Sipuncula). Zool. Jour. Linn. Soc. 65: 367-384.

Cutler, F.B. and N.J. Cutler. 1979. Madagascar and Indian Ocean Sipuncula. Bull. Mus. natn. Hist. nat., 4/ ser., 1, sec. A, n/ 4: 941-990.

Cutler, E.B. and E. Jurczak. 1975. The sipunculan genus Lithacrosiphon Shipley, a taxonomic review. Zool. Jour. Linn. Soc. 56 (3) : 235-248.

Cutler, E.B. and V.V. Murina. 1977. On the sipunculan genus Golfingia Lankester, 1885. Zool. Jour. Linn. Soc. 60: 173-189.

Edmonds, S.J. 1971. Some sipunculans and echiurans, chiefly from Guam (Sipuncula and Echiura). Micronesica 7 (1-2): 137-151.

Fischer, W. 1919. Gephyrean der Sud-westkuste Australiens. Zool. Anz, 50: 277-285.

Fisher, W.K. 1950. The sipunculid genus Phascolosoma. Ann. Mag. Nat. Hist. ser. 12, 3: 547-552. 1952. The sipunculid worms of California and Baja California. Proc. U.S. Natn. Mus. 102: $371-450$.

Gibbs, P.E. 1973. On the genus Golfingia (Sipuncula) in the Plymouth area with a description of a new species. J. mar. biol. Ass. U.K. 53: 73-86.

1977. British sipunculans. Synopses of the British Fauna (new series). No 12, 35 pp. The Linnean Soc. Lond.

Ikeda, I. 1904. The gephyrea of Japan. Jour. Coll. Sci., Imp. Univ. Tokyo 20: 1-87.

1905. Gephyreans collected by Professor Dean at Manjuyodi, Southern Negros (Philippine Is.). Annotationes Zoologicae Japonenses 5: 169-174.

1924. 2. Further notes on the Gephyrea of Japan, with descriptions of some new species from the Marshall, Caroline, and Palau Islands. Japanese Jour. Zool. 1: $23-44$.

Lanchester, W.F. 1905. On the sipunculids and echiurids collected during the "Skeat" Expedition to the Malay Peninsula. Proc. Zool. Soc. London 1: 35-41.

Leroy, P. 1936. Les sipunculiens du Museum d'Historie Naturelle de Paris. Bull. Mus. natn. d'hist. nat. Paris, ser. 2, 8: 423-426.

Murina, V.V. 1964. Report on the sipunculid worms from the coast of South-Chinese Sea. Trudy Inst. Ocean. 69: 254-270.

1967a. Report on the sipunculid worms from the sublittoral zone of Cuba and Mexican Gulf. Zool. Zhur. 46 (9): 1329-1339.

1967b. On the sipunculid fauna of the littoral of Cuba. Zool. Zhur. 46: 35-47.

1975. New taxa of the genus Golfingia. Zool. Zhur. 54: 1085-1089. 
1977. Sipunculans of the Arctic and boreal parts of the Eurasian seas. Works on the fauna of USSR, Zool. Inst. USSR $283 \mathrm{pp}$.

1978. On the sipunculids and priapulids fauna of the southern Pacific. Trudy Inst. Ocean. 113: $120-131$.

Okuda, S. 1946. The fauna of Akkeshi Bay. XV. Gephyrea. Contrib. Akkeshi Mar. Biol. Lab. 43: 221-225.

Rice, M.E. 1978. Morphological and behavioral changes at metamorphosis in the Sipuncula. In Chia and Rice, Eds. Settlement and metamorphosis of marine invertebrate larvae, pp. 83-102. Elsevier North-Holland Biomedical Press, New York.

Sato, H. 1930. Report on the biological survey of Mutsu Bay. 15. Sipunculoidea. Sci. Rept. Tohoku Imp. Univ. ser. 4 Biol. 5: 1-40.

1934. Report on the sipunculoidea, echiuroidea, and priapuloidea collected by the SoyoMaru Expedition of 1922-1930. Ibid. 9: 1-32.

1935. Sipunculoidea and Echiuroidea of the West Caroline Islands. Ibid. 10: 299-329.

1937a. Echiuroidea, Sipunculoidea, and Priapuloidea obtained in northeast Honshu, Japan. Saito Ho-On Kai Mus., Res. Bull. 12: 137-176.

1937b. Note on a new sipunculid, Physcosoma kurilense n. sp. found in Shumshir Island. Annotationes Zoologicae Japonenses 16: 117-120.

- 1939. Studies on the Echiuridae, Sipunculids, and Priapulids of Japan. Sci. Rept. Tohoku Imp. Univ. ser, $4,14(4): 339-459$.

Selenka, E., J.G. deMan, and G. Bulow. 1883. Die Sipunculiden, eine systematische Monographie. Reisen im Archipel Philippinen von Dr. C. Semper. Leipzig \& Wiesbaden pt. 2, 4 (1): 1-133.

Shipley, A.E. 1892. A new species of Phymosoma. Proc. Camb. phil. Soc. biol. Sci. 7: 77-78.

Stephen, A.C. 1942. The South African intertidal zone and its relation to ocean currents. Notes on the intertidal sipunculids of Cape Province and Natal. Annals Natal Mus. 10 (2): 245-256.

1952. The "Mannhini" Expedition to the Gulf of Aquaba. V. Gephyrea. Bull. Brit. Mus. (nat. Hist.) Zool. 1: 181-182.

1960. British Echiurids (Echiuroidea), sipunculids (Sipunculoidea), and priapulids (Priapuloidea). Linn. Soc. London. Synopses of the British Fauna No. 12.

Stephen, A.C. and E.B. Cutler. 1969. On a collection of Sipuncula, Echiura, and Priapulida from South African waters. Trans. roy. Soc. S. Afr. 38: 111-121.

Stephen, A.C. and S.J. Edmonds. 1972. The phyla Sipuncula and Echiura. London: British Museum (Nat. Hist.). 528 pp.

Wesenberg-Lund, E. 1957. Sipunculoidea and Echiuroidea from the Red Sea. Contributions to the knowledge of the Red Sea No. 3. Sea. Fish. Res. Stat., Haifa Bull. 14: 1-15.

1959. Sipunculids and echiuridae from Mauritius. Vidensk. Medd. dansk. nat. Foren Kbh. $121: 53-73$.

1963. South African sipunculids and echiuroids from coastal waters. Vidensk. Medd. dansk. nat. Foren Kbh. 125: 101-146. 